Article

\title{
Optimization of Passive Envelop Energy Efficient Measures for Office Buildings in Different Climate Regions of China Based on Modified Sensitivity Analysis
}

\author{
Zhaoxia Wang and Jing Zhao * id \\ School of Environmental Science and Engineering, Tianjin University, Tianjin 300072, China; \\ zhaoyiwang@tju.edu.cn \\ * Correspondence: zhaojing@tju.edu.cn; Tel.: +86-022-2740-9188
}

Received: 4 February 2018; Accepted: 19 March 2018; Published: 21 March 2018

\begin{abstract}
With the growing desire for new buildings and better indoor comfort, the amount of energy consumption of office buildings in China is increasing rapidly, which will lead to the great challenge for energy supply and sustainable development. Building passive envelop energy efficient measures (PEEEMs), mainly including exterior wall insulation, roof insulation, different glazing types, and shading system, were widely applied. However, the specific energy efficient performance of PEEEMs was various in different climate conditions that have not been evaluated clearly yet. The priority order of PEEEMs was not recommended in relative standards. The economic benefits cannot be considered synchronously with PEEEMs optimization. This paper modified the sensitivity analysis to fit the building energy efficiency evaluation. By combining the modified method with a simulation tool, the energy efficiency and economic effects of PEEEMs of office buildings in various climate regions can be considered at the same time. Four case buildings in Shenyang, Tianjin, Ningbo, and Shenzhen were proved to reach the energy-saving potentials of $9.44 \%, 7.75 \%, 20.87 \%$, and $13.27 \%$ respectively, with the payback period of no more than 1.5 years. Finally, the recommended application priority rankings and the recommended ranges of thermal performance properties of PEEEMs in the four typical climate regions were presented.
\end{abstract}

Keywords: passive envelop energy efficient measures (PEEEMs); modified sensitivity analysis; climate regions; case study; application priority ranking

\section{Introduction}

Building energy consumption, which has already taken as much as $40 \%$ of the total energy use and $36 \%$ of the carbon dioxide emissions all over the world [1] and is estimated to quickly augment with future building development, is a significant sector, influencing sustainable development of the whole society. Among all the buildings with different functions, office buildings have already been one of the fastest growing groups, especially in large cities. The total energy consumption of office buildings with full sets of air-conditioning systems is about $70-300 \mathrm{kWh} /\left(\mathrm{m}^{2} \cdot \mathrm{a}\right), 10-20$ times more than that of residential buildings in China [2]. Building energy efficiency has been paid great attention to realize sustainable development during the rapid urbanization phase. Passivhaus is one of the fastest growing energy efficient buildings with the strength of simplicity of the concept [3] and low costs. Voss K. et al. [4] estimated the active and passive cooling measures in 22 demonstration projects. Results showed that $1 / 3$ energy consumption has been saved by passive measures without greatly increased cost. Building envelop plays an extremely significant role in passivhaus. The main principle of building passive envelop energy efficient measures (PEEEMs) is preventing heat loss during 
the heating period and reducing heat gain while cooling. Exterior wall insulation, roof insulation, glazing types, and shading systems are the four typical PEEEM that are widely applied. The energy performance of the PEEEMs is usually considered as a premise of other building energy efficient measures, for example, heating and cooling systems and renewable energy. So, the optimization of PEEEMs is of great significance during building energy efficient design.

Many building energy efficient design standards have clarified the technical indexes of these PEEEMs internationally, nationally, and locally $[5,6]$. For example, the limits of $U$-value of exterior walls, windows, roof, and sun-shading coefficient of exterior windows are clearly listed in Chinese national standard series of GB $50189[7,8]$. However, the limited values in national standards are generally low because of various building features. Based on the standards, if the building designers want to partially improve the building energy efficient performance, the optimization order or recommended range of thermal performance properties of exterior walls, windows, and roof should be recommended. In addition, the recommended value ranges can be properly improved in local standards. The selection of indexes should be improved must be based on the energy efficiency performance of PEEEMS.

It is fairly difficult to estimate the performance of PEEEMs with various designs in different climate conditions [9-11]. Related to the effect evaluation of these PEEEMs, many scholars have made their points. Zhou S. and Zhao J. [12] studied the building envelop energy saving technologies for office buildings in different climate regions by establishing virtual building models. However, the study cases were experimental rather than real buildings. Wang Z., Ding Y. et al. [13] analyzed a retrofit office building in cold regions of China and pointed out that the building envelop energy efficiency retrofit, including exterior walls, roof and windows, was an important premise to realize the energy efficient effects. Otherwise, the energy-saving goal would not be reached or even ending up with low energy efficiency because of the overload of building itself. Østergård T. et al. [14] proposed a systematic model to perform, analyze, and visualize simulations of a global design space in order to guide decision-making in a multi-collaborator context. Even in early design stage, the key factors of envelopes such as wall structure and materials, roofs, windows, shading, etc. were significantly considered. Yang L. et al. [15] conducted research on energy performance of office building envelop designs through overall thermal transfer value (OTTV) method. It was confirmed that certain building envelopes tended to obtain more heat gain/loss than those specified by the local design/energy codes and some useful recommendations were proposed to improve the energy efficiency of the building. Yu J. et al. [16] used eQUEST to analyze envelop design on air-conditioning energy-saving of residential buildings. Energy efficient technologies including exterior wall thermal insulation, solar radiation absorptance of exterior wall, area ratio of window to wall, categories of glazing and kinds of shading system, and two combined strategies were evaluated. The results indicated that envelope shading and exterior wall thermal insulation were the best strategies in hot summer and cold winter zone to decrease the air conditioning electricity consumption. In the case study, the saving rate of 11.31 and $11.55 \%$ were achieved respectively. The optimization of different strategies could decrease the annual cooling and heating electricity consumption by $21.08 \%$ and $34.77 \%$ respectively. In the above research, the study emphases were energy-saving potential of different strategies. Economic benefits were taken as a posterior condition, and were calculated after deciding the energy efficiency strategies. It means if the design scheme is not available from the aspect of investment, the design scheme and economic calculation should be reworked. However, the economic analysis may be complicated for various design schemes. Additionally, the priority orders of energy efficient measures are generally decided by the economic benefits of PEEEMs. A method considering the energy efficient performance and economic benefits of PEEEMs at the same time is necessary during design stage.

In order to evaluate the energy efficient effects of PEEEMs in the different climate regions, sensitivity analysis, combining with building energy simulation software, was applied. Sensitivity analysis can help understanding of the relative influence of input parameters on the outputs [17]. In the field of energy efficiency, sensitivity analysis can be significantly useful for selecting the 
most appropriate energy efficient measures and balancing the energy-saving effect and economic benefits $[18,19]$. Previous research mainly focused on the suitability of different PEEEMs in specific climate regions, while the optimum combinations of various PEEEMs in different climate regions were seldom concerned [20]. Therefore, this paper focused on the optimization of PEEEMs applied in office buildings in different climate regions of China to realize maximum effect by limited costs.

PEEEMs are widely applied in four typical climate regions in China, namely the severe cold (SC) region, cold (CC) region, hot summer and cold winter (HS/CW) region, hot summer and warm winter (HS/WW) region. Four office buildings in Shenyang (SC region), Tianjin (CC region), Ningbo (HS/CW region) and Shenzhen (HS/WW region) were selected as case buildings. Based on the four case buildings, the following sections were organized as follows. Building energy simulation models were established and verified for case buildings in each climate region respectively in Section 2.1. Sensitivity coefficient suitable in building energy efficiency field was defined in Section 2.2. Based on the above methodologies, different dimensions for each PEEEM and corresponding energy consumption were listed. Sensitivity coefficient values for each PEEEM were calculated in Section 3. The PEEEMs application priority rankings suitable for the four typical climate regions of China were presented in Section 4. Some supplement and explanation, including theoretical economic benefits, indoor comfort and other passive building energy efficient measures, were discussed in Section 5 . Conclusions were summarized in Section 6.

\section{Methodology}

\subsection{Building Energy Consumption Simulation and Verification}

In order to recommend the best measures for passive building energy efficient technologies, various levels of PEEEMs should be explored. Building energy simulation is an important measure to explore various conditions that cannot be complemented in reality. DesignBuilder is one of the most comprehensive user interfaces for EnergyPlus dynamic thermal simulation engine [21-23]. It can generate detailed building energy performance data for a whole year. ASHRAE (American Society of Heating, Refrigerating and Air Conditioning Engineers) conducted a series of special testing programs for application range of building energy consumption simulation \& thermal environment on simulation ability and building environment control system based on ANSI/ASHRAE Standard 14-2002 [24]. The evaluation results of DesignBuilder were consistent with that of EnergyPlus, which indicates that DesignBuilder is appropriate for most cases of building energy consumption simulation [25].

After establishing the energy simulation model, the simulated results should be verified. Normalized mean bias error (NMBE) and coefficient of variation of the root mean square error (CVRMSE) are introduced in ASHRAE Guideline 14-2002 [24], whose expressions are presented as Equations (1) and (2) [24]. ASHRAE Guideline 14-2002 suggests that the simulation results compared with the measured energy consumption should be reliable under the condition that the NMBE and CVRMSE were less than $5 \%$ and $15 \%$ respectively [24].

$$
\begin{gathered}
\text { NMBE }=\frac{\sum_{i=1}^{n}\left(E_{s i}-E_{m i}\right)}{(n-p) \times \bar{E}_{m}} \times 100 \\
\text { CVRMSE }=100 \times\left[\sum\left(E_{s i}-E_{m i}\right)^{2} /(n-p)\right]^{\frac{1}{2}} / \bar{E}_{m}
\end{gathered}
$$

where $E_{s i}$ is the simulated energy consumption of month $i(\mathrm{kWh}) ; E_{m i}$ is the measured energy consumption of month $i(\mathrm{kWh}) ; \bar{E}_{m}$ is the average value of measured monthly energy consumption $(\mathrm{kWh}) ; i$ is month and $n$ is the total month of a year, $n=12 ; p=1$.

Five typical climate regions are classified in China, generally the severe cold (SC) region, cold (CC) region, hot summer and cold winter (HS/CW) region, hot summer and warm winter (HS/WW) region and mild region. The climate regions are divided based on monthly average temperature and heating 
degree days (HDD $18,{ }^{\circ} \mathrm{C} \cdot$ day) and cooling degree days $\left(\mathrm{CDD} 26,{ }^{\circ} \mathrm{C} \cdot\right.$ day). The climate characteristics are listed in Table 1 [26]. Specifically, the climate in temperate regions is relatively comfortable for human beings and heating and cooling requirements for buildings are weak. So, in this research, the temperate region is not discussed.

Table 1. Climate regions in civil building thermal design [26].

\begin{tabular}{|c|c|c|c|}
\hline \multirow{2}{*}{ Name } & \multicolumn{2}{|c|}{ Indexes } & \multirow{2}{*}{ Typical City } \\
\hline & Leading Index & Auxiliary Index & \\
\hline Severe cold (SC) regions & $\begin{array}{l}\text { Average temperature of the } \\
\text { coldest month } \leq-10{ }^{\circ} \mathrm{C}\end{array}$ & $\mathrm{HDD} \geq 145^{\circ} \mathrm{C} \cdot$ day & Shenyang \\
\hline Cold (CC) regions & $\begin{array}{l}-10^{\circ} \mathrm{C}<\text { Average temperature of } \\
\text { the coldest month } \leq 0^{\circ} \mathrm{C}\end{array}$ & $\begin{array}{l}90^{\circ} \mathrm{C} \cdot \text { day } \leq \mathrm{HDD} \leq \\
45^{\circ} \mathrm{C} \cdot \text { day }\end{array}$ & Tianjin \\
\hline $\begin{array}{l}\text { Hot summer and cold } \\
\text { winter }(\mathrm{HS} / \mathrm{CW}) \text { regions }\end{array}$ & $\begin{array}{l}-10^{\circ} \mathrm{C}<\text { Average temperature of } \\
\text { the coldest month } \leq 0{ }^{\circ} \mathrm{C} \text {; } \\
25^{\circ} \mathrm{C} \leq \text { Average temperature of } \\
\text { the hottest month } \leq 30^{\circ} \mathrm{C}\end{array}$ & $\begin{array}{l}\mathrm{HDD} \leq 90^{\circ} \mathrm{C} \cdot \text { day } \\
40^{\circ} \mathrm{C} \cdot \text { day } \leq \mathrm{CDD} \leq \\
110^{\circ} \mathrm{C} \cdot \text { day }\end{array}$ & Ningbo \\
\hline $\begin{array}{l}\text { Hot summer and warm } \\
\text { winter (HS/WW) regions }\end{array}$ & $\begin{array}{l}\text { Average temperature of the } \\
\text { coldest month }>10^{\circ} \mathrm{C} \text {; } \\
25^{\circ} \mathrm{C}<\text { Average temperature of } \\
\text { the hottest month } \leq 29^{\circ} \mathrm{C}\end{array}$ & $\begin{array}{l}100^{\circ} \mathrm{C} \cdot \text { day } \leq \mathrm{CDD} \leq \\
200^{\circ} \mathrm{C} \cdot \text { day }\end{array}$ & Shenzhen \\
\hline $\begin{array}{l}\text { Temperate regions } \\
\text { (not discussed) }\end{array}$ & $\begin{array}{l}0^{\circ} \mathrm{C}<\text { Average temperature of the } \\
\text { coldest month } \leq 13^{\circ} \mathrm{C} \text {; } \\
18^{\circ} \mathrm{C} \leq \text { Average temperature of } \\
\text { the hottest month } \leq 25^{\circ} \mathrm{C}\end{array}$ & $\mathrm{HDD} \leq 90{ }^{\circ} \mathrm{C} \cdot$ day & Sanya \\
\hline
\end{tabular}

Four office buildings were selected as case study buildings in this study. All of the four office buildings are medium sized and air-conditioned, with $60-80 \%$ practical occupancy rate. They are located in Shenyang, Tianjin, Ningbo, and Shenzhen, which can respectively represent the belonging typical climate regions of China. It is important that the case buildings are all well designed and constructed according to the 2005 edition of Design Standard for Energy Efficiency of Public Buildings (GB 50189-2005) [7]. Though this standard has been modified in 2014 [14], the 2005 edition was the mandatory standard when the buildings were built. The annual energy usage intensity (EUI) of case buildings, quotient of the energy consumption and the corresponding gross floor area, representing the building energy consumption level, are relatively low among office buildings in each climate region. A summary of main information of the case buildings, including general building information, air-conditioning system, energy efficient technologies and annual energy consumption, was shown in Table 2. 
Table 2. Case building description.

\begin{tabular}{|c|c|c|c|c|}
\hline Location & Shenyang & Tianjin & Ningbo & Shenzhen \\
\hline \multicolumn{5}{|c|}{ Climate parameters of typical meteorological year } \\
\hline Climate region & Severe cold region & Cold region & Hot summer and cold winter region & Hot summer and warm winter region \\
\hline $\begin{array}{l}\text { Average temperature of the coldest } \\
\text { month (Jan.) }\end{array}$ & $-11.5^{\circ} \mathrm{C}$ & $-2.4^{\circ} \mathrm{C}$ & $3.7^{\circ} \mathrm{C}$ & $16.2^{\circ} \mathrm{C}$ \\
\hline $\begin{array}{l}\text { Average temperature of the warmest } \\
\text { month (Jul.) }\end{array}$ & $24.5^{\circ} \mathrm{C}$ & $26.1^{\circ} \mathrm{C}$ & $27.8^{\circ} \mathrm{C}$ & $29.8^{\circ} \mathrm{C}$ \\
\hline HDD18 $\left({ }^{\circ} \mathrm{C} \cdot\right.$ day $)$ & 4062 & 2738 & 981 & 272 \\
\hline $\mathrm{CDD} 26\left({ }^{\circ} \mathrm{C} \cdot\right.$ day $)$ & 486 & 566 & 1650 & 2141 \\
\hline \multicolumn{5}{|l|}{ Building information } \\
\hline Gross floor area $\left(\mathrm{m}^{2}\right)$ & $10,997.38$ & 7525 & 4760 & 16,600 \\
\hline Building type & Office & Office & Office & Office \\
\hline Building height $(\mathrm{m})$ & 19.8 & 23.85 & 20.2 & 20.5 \\
\hline Number of floors & 5 & 6 & 5 & 5 \\
\hline Floor height (m) & 3.9 & 3.5 & 3.5 & 3.9 \\
\hline \multicolumn{5}{|l|}{ Building operation information } \\
\hline Working time & 8:00-17:00 & 9:00-18:00 & 9:00-18:00 & 9:00-17:30 \\
\hline $\begin{array}{l}\text { Occupant density of working zone } \\
\left(\text { people } / \mathrm{m}^{2}\right)\end{array}$ & 0.08 & 0.125 & 0.15 & 0.25 \\
\hline Commonly occupant number & Around 650 & Around 400 & Around 300 & Around 700 \\
\hline $\begin{array}{l}\text { Indoor equipment power density } \\
\left(\mathrm{W} / \mathrm{m}^{2}\right)\end{array}$ & 6.2 & 20 & 6 & 20 \\
\hline Lighting density $\left(\mathrm{W} / \mathrm{m}^{2}\right)$ & 3.8 & 9 & 4 & 5.2 \\
\hline \multicolumn{5}{|l|}{ Envelop form and thermal parameters } \\
\hline \multicolumn{5}{|l|}{ Exterior wall } \\
\hline Form & EPS & EPS & EPS & EPS \\
\hline EPS layer thickness (mm) & 60 & 80 & 115 & 10 \\
\hline $\mathrm{U}$ value of the exterior walls $\left(\mathrm{W} / \mathrm{m}^{2} \cdot \mathrm{K}\right)$ & 0.51 & 0.39 & 0.295 & 1.26 \\
\hline
\end{tabular}


Table 2. Cont.

\begin{tabular}{|c|c|c|c|c|}
\hline Location & Shenyang & Tianjin & Ningbo & Shenzhen \\
\hline \multicolumn{5}{|l|}{ Roof } \\
\hline Form & EPS & EPS & EPS & EPS \\
\hline EPS layer thickness (mm) & 135 & 70 & 135 & 30 \\
\hline $\mathrm{U}$ value of the roof $\left(\mathrm{W} / \mathrm{m}^{2} \cdot \mathrm{K}\right)$ & 0.25 & 0.42 & 0.248 & 0.67 \\
\hline \multicolumn{5}{|l|}{ Exterior window } \\
\hline Glazing type & $\begin{array}{l}\text { Double layers, reflective + } \\
\text { Clear } 6 \mathrm{~mm} / 13 \mathrm{~mm} \text { air }\end{array}$ & $\begin{array}{c}\text { Double layers, } \\
\text { electrochromism +Clear } 6 \\
\mathrm{~mm} / 13 \mathrm{~mm} \text { Air }\end{array}$ & Double layers, low-E $+3 \mathrm{~mm} / 6 \mathrm{~mm}$ air & $\begin{array}{l}\text { Double layers, reflective + Clear } 6 \\
\mathrm{~mm} / 13 \mathrm{~mm} \text { air }\end{array}$ \\
\hline Solar heat gain coefficient (SHGC) & 0.176 & 0.6 & 0.687 & 0.176 \\
\hline $\mathrm{U}$ value of the windows $\left(\mathrm{W} / \mathrm{m}^{2} \cdot \mathrm{K}\right)$ & 2.2 & 1.72 & 2.58 & 2.2 \\
\hline Ratio of window to wall (\%) & 20 & 25 & 50 & 90 \\
\hline Shading & $\begin{array}{l}\text { Interior shading of diffusing } \\
\text { blinds, no exterior shading }\end{array}$ & $\begin{array}{l}\text { Interior shading of diffusing } \\
\text { blinds, no exterior shading }\end{array}$ & $\begin{array}{l}\text { Interior shading of diffusing blinds, exterior } \\
\text { shading of } 0.5 \mathrm{~m} \text { overhanging board }\end{array}$ & $\begin{array}{l}\text { Interior shading of diffusing blinds, } \\
\text { exterior shading of } 1.0 \mathrm{~m} \text { louver }\end{array}$ \\
\hline \multicolumn{5}{|l|}{ Indoor design parameters } \\
\hline Indoor temperature in summer $\left({ }^{\circ} \mathrm{C}\right)$ & 26 & 26 & 26 & 26 \\
\hline $\begin{array}{l}\text { Indoor relative humidity in summer } \\
(\%)\end{array}$ & 55 & 55 & 60 & 60 \\
\hline Indoor temperature in winter $\left({ }^{\circ} \mathrm{C}\right)$ & 20 & 20 & 20 & 20 \\
\hline Indoor relative humidity in winter (\%) & 35 & 35 & 35 & 35 \\
\hline $\begin{array}{l}\text { Design fresh air volume } \\
\left(\mathrm{m}^{3} / \text { person } / \mathrm{h}\right)\end{array}$ & 30 & 30 & 30 & 30 \\
\hline \multicolumn{5}{|l|}{ Heating and cooling information } \\
\hline Cooling supply period & 1 June-30 September & 1 June-30 September & 1 June-30 September & 1 April-1 November \\
\hline Heating supply period & 1 November-31 March & 15 November-15 March & 1 December-15 February & none \\
\hline Heating and cooling unit type & $\begin{array}{l}\text { Ground source heat pump } \\
\text { (GSHP) }\end{array}$ & GSHP & VAV system & Electrical air-handling unit \\
\hline Design systematic COP & 5.3 & 4.5 & 3.3. & 2.5 \\
\hline \multicolumn{5}{|l|}{ Total energy consumption } \\
\hline Annual energy consumption (kWh) & $1,099,123$ & $612,427.38$ & $283,124.8$ & $2,544,400$ \\
\hline Annual EUI $\left(\mathrm{kWh} /\left(\mathrm{m}^{2} \cdot \mathrm{a}\right)\right)$ & 99.94 & 81.37 & 59.48 & 153.27 \\
\hline
\end{tabular}


Dynamic energy simulation tool DesignBuilder was applied in the energy efficiency performance simulation of the case buildings. Based on the design drawings and practical information, four case building models were established by DesignBuilder, as shown in Figure 1. The building information, including envelop parameters, window-wall ratio, working schedule of the air-conditioning systems, occupancy densities, lighting densities, equipment densities of the building models, were set exactly according to the practical status of the case buildings, as shown in Table 2. The typical meteorological year weather data in the four cities was adopted as the input outdoor weather data.

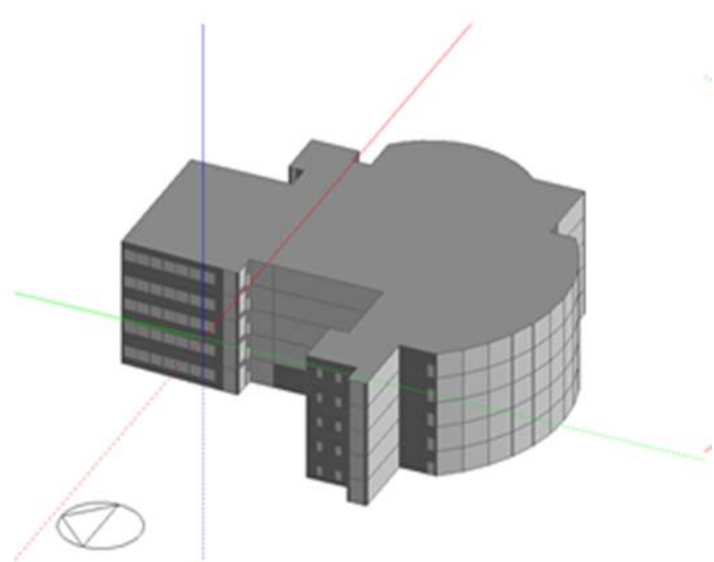

(a)

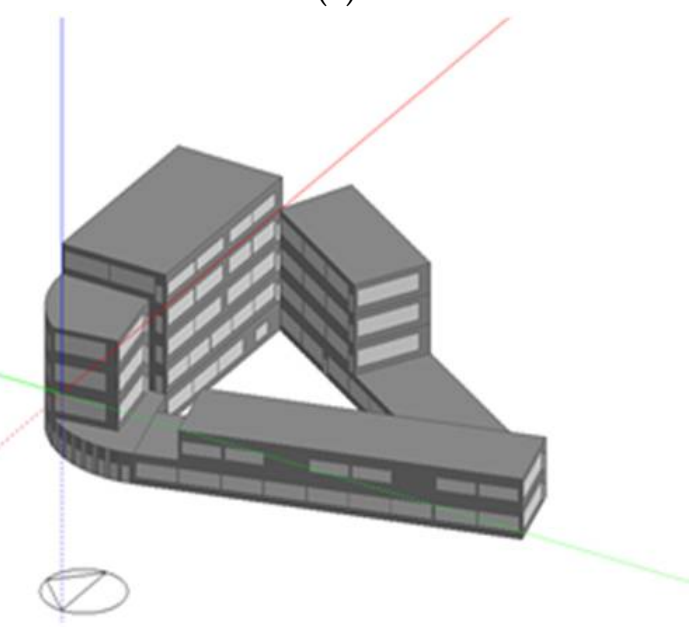

(c)

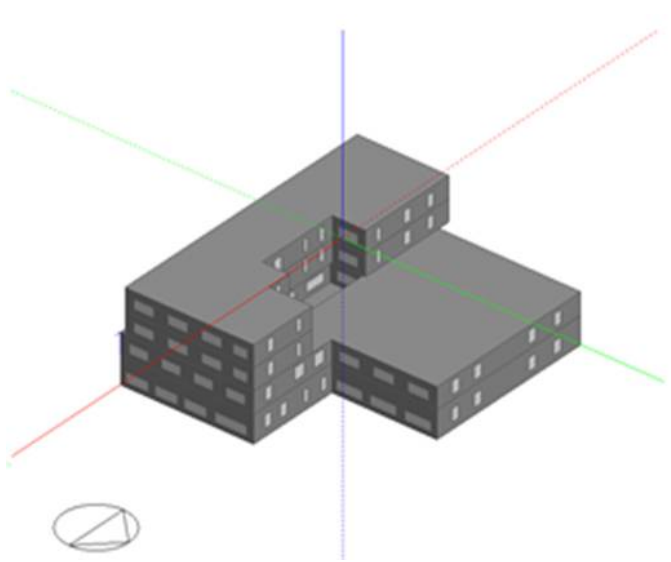

(b)

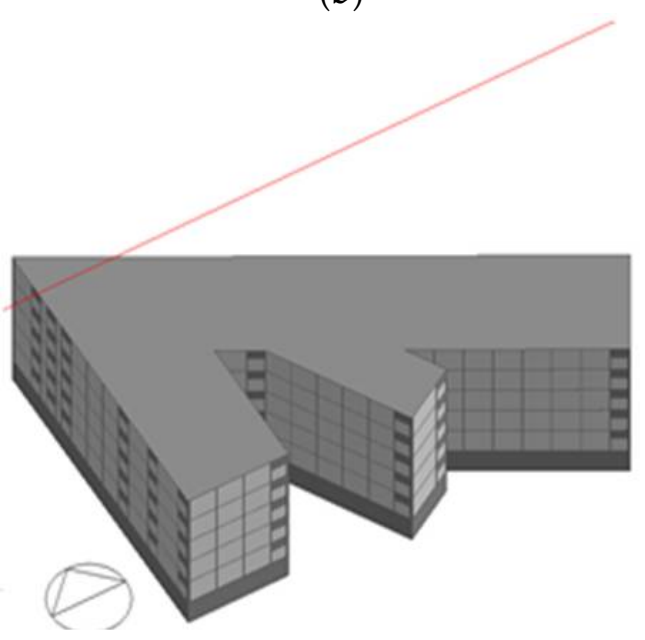

(d)

Figure 1. Photos of simulation models of case buildings in DesignBuilder. (a) Simulation model of case building in Shenyang; (b) Simulation model of case building in Tianjin; (c) Simulation model of case building in Ningbo; (d) Simulation model of case building in Shenzhen.

After built the energy consumption model, the accuracy of simulation results should be tested. Comparison between the actual monthly energy consumption data and simulation data was conducted and shown in Figure 2. 


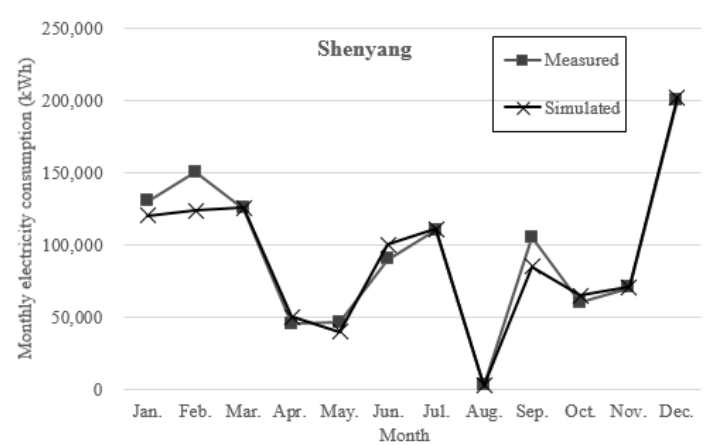

(a)

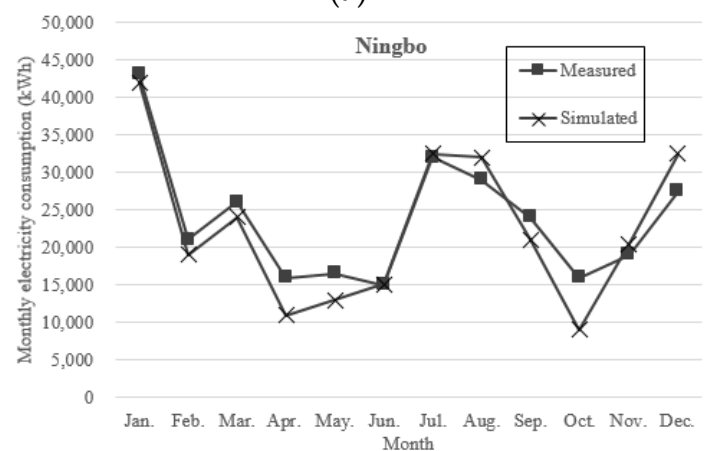

(c)

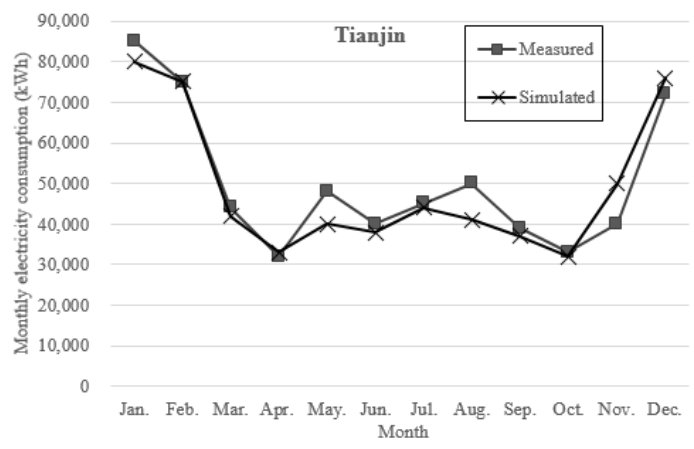

(b)

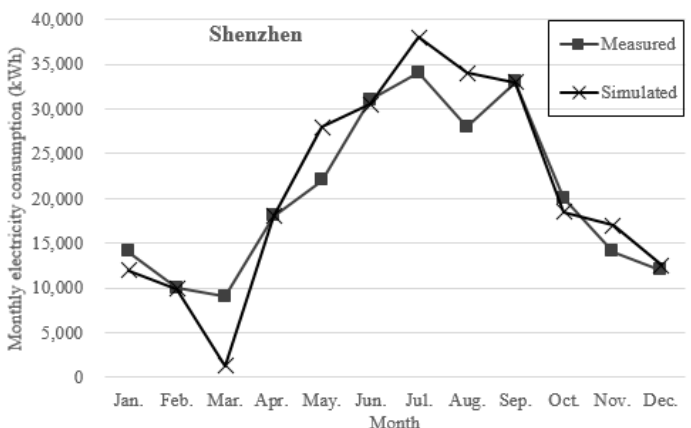

(d)

Figure 2. Comparison of measured and simulated monthly energy consumption. (a) Building in Shenyang, SC region; (b) Building in Tianjin, CC region; (c) Building in Ningbo, HS/CW region; (d) Building in Shenzhen, HS/WW region.

The energy form of case buildings is electricity. The actual energy consumption of case buildings was collected from their energy bills based on electricity meters. As illustrated in Figure 2, the simulated energy consumption tends to follow the measured data quite closely and their variation trends seem the same. The major reasons of the variations could be considered as the following. Firstly, the climate conditions of the simulation models were typical meteorological year weather data, which were different with actual weather data. Secondly, the operation time of the simulation models were certain values while the actual operation time might be various because of special activities. Above all, the variations between simulated energy consumption and measured ones were not caused by PEEEMs of case buildings.

In order to reveal the degree of difference between simulated and measured energy consumption more visually, a summary of the NMBEs and CVRMSEs of the case buildings according to the calculation based on Equations (1) and (2) was listed in Table 3. So, the influences of building energy consumption caused by the envelop parameter changes of the building models can be reflected and predicted in the practical situation of case buildings. The verification provided scientific and rational foundation of sensitivity analysis adopted in this research below.

Table 3. Comparison between measured value and simulated value [24].

\begin{tabular}{cccccc}
\hline Criteria & ASHRAE & Shenyang & Tianjin & Ningbo & Shenzhen \\
\hline NMBE $(\%)$ & \pm 5 & 2.84 & 1.84 & 3.40 & -3.54 \\
CVRMSE $(\%)$ & \pm 15 & 12.04 & 9.11 & 12.16 & 11.16 \\
\hline
\end{tabular}

\subsection{Modified Sensitivity Analysis}

Sensitivity analysis theory refers to the observation method on responsive variations caused by motivation changes. It originally is an economic analysis method to select significant parameters 
from various uncertain ones and validate the influent effects on economic benefits [27]. Application of the method is growing in various fields of science in recent years, such as physics, electronics, and environics [28-30]. In particular, sensitivity analysis is also used in building energy efficiency study [31,32]. This method especially aims at deciding the best parameter value for an optimized selection by altering a certain parameter while keeping others remain unchanged [33]. Sensitivity coefficient, the measurement of sensitivity indicating the importance of input parameters to the outputs, can be calculated by Equation (3).

$$
\text { Sensitivity Coefficient }=\frac{\text { OPchange } \%}{I \text { Pchange } \%} \approx \frac{\Delta O P \div O P_{B}}{\Delta I P \div I P_{B}}
$$

where IPchange $\%$ and OPchange $\%$ are the differential rate of input and output value comparing with the base case; $\triangle O P$ and $\triangle I P$ are the variation of output and input value; $O P_{B}$ and $I P_{B}$ are the base cases of output and input value.

If the input parameters are more than one and cannot be divided, the sensitivity coefficient calculation equation should be modified. The sensitivity analysis was modified to fit the situation of more than one input parameters. The significance level of these input parameters should be evaluated first. The non-significant parameters can then be ignored. For significant parameters, the contribution weight of each parameter should be calculated, and the modified sensitivity coefficient can be calculated by the weighted sensitivity coefficient of each parameter. The weighted sensitivity coefficient was defined as

$$
\text { Weighted Sensitivity Coefficient }=\sum_{2}^{\lambda} w_{j} \times\left(\frac{\Delta O P \div O P_{B}}{\Delta I P \div I P_{B}}\right)_{j}
$$

where $j$ is one of the input parameters and $\lambda$ is the number of the significant input parameters.

Sensitivity analysis requires reference object, which is called base case for sensitivity coefficient calculation. With the purpose of obtaining the precise sensitivity coefficients of all types of PEEEMs in each climate regions of China, the values of initial building envelop input parameters of the four case buildings were defined as the base case values.

In order to identify the influence on building energy efficiency performance of particular changes imposed by building envelopes, the characteristic parameters of building envelop were set as input variables. According to Equations (3) and (4), the detailed calculation of modified sensitivity coefficient for PEEEMs is shown as follows.

(1) Insulation of exterior walls and roof. The comprehensive heat transfer coefficient (U-value) is the main thermal parameter of exterior wall and roof. So, the sensitivity coefficient of insulation of exterior walls and roof was defined as Equation (5).

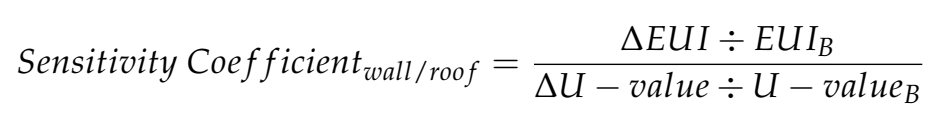

where $\Delta E U I$ is the variation of energy usage intensity (EUI), $\mathrm{kWh} /\left(\mathrm{m}^{2} \cdot \mathrm{a}\right) ; E U I_{B}$ is the baseline of EUI, $\mathrm{kWh} /\left(\mathrm{m}^{2} \cdot \mathrm{a}\right) ; \Delta U-$ value is the variations of the comprehensive heat transfer coefficient of exterior walls and roof, $\mathrm{W} /\left(\mathrm{m}^{2} \cdot \mathrm{K}\right) ; U-$ value $_{B}$ is the baseline of the comprehensive heat transfer coefficient of exterior walls and roof, $\mathrm{W} /\left(\mathrm{m}^{2} \cdot \mathrm{K}\right)$.

(2) Exterior windows. Shading and glazing are the two main parts of exterior windows which influencing the building energy consumption. The influence mechanism of the two parts is different. The shading system mainly influences the radiation heat from the sun to indoor air. Heat transfer through glazing includes heat conduction, convection and radiation at the same time. In addition, the type of glazing can influence the energy consumption of HVAC and lighting at the same time. So, shading system and glazing of exterior windows were discussed separately in this paper. 
The overall shading coefficient (OSC) of shading system is the characteristic parameter of shading system. So the sensitivity coefficient of shading system is

$$
\text { Sensitivity Coefficient }_{\text {shading }}=\frac{\Delta E U I \div E U I_{B}}{\Delta O S C \div O S C_{B}}
$$

where $\triangle O S C$ is the variation of the overall shading coefficient of building shading system; $O S C_{B}$ is the baseline of the overall shading coefficient.

The comprehensive heat conduction coefficient (U-value) and solar heat gain coefficient (SHGC) are two important parameters describing the thermal performance of glazing [26]. Visible transmittance of glazing is the rate of visible light transmitting through glasses from outdoor to indoor to the total luminous flux illuminating on the glasses. It is the parameter describing the light transmittance performance of glazing [26]. So the HVAC energy consumption is influenced by U-value and SHGC at the same time. SHGC and visible transmittance may impact the lighting energy consumption based on lighting control. Total energy consumption can be influenced by the three parameters, which are certain values if a type of glass is selected. So the parameters cannot be analyzed separately and weighted sensitivity coefficient was adopted. As for the glazing of exterior windows, the weighted sensitivity coefficient to total energy consumption can be calculated by Equation (7).

$$
\begin{gathered}
\text { Sensitivity Coefficient } t_{\text {glazing }}=w_{U-\text { value }} \frac{\Delta E U I \div E U I_{B}}{\Delta U-v a l u e \div U-\text { value }_{B}}+ \\
w_{S H G C} \frac{\Delta E U I \div E U I_{B}}{\Delta S H G C \div S H G C_{B}}+w_{v t} \frac{\Delta E U I \div E U I_{B}}{\Delta v t \div v t_{B}}
\end{gathered}
$$

where $\Delta U$ - value, $\triangle S H G C$ and $\Delta v t$ are the variations of the comprehensive heat transfer coefficient of exterior windows, $\mathrm{W} /\left(\mathrm{m}^{2} \cdot \mathrm{K}\right)$, the solar heat gain coefficient of glazing and the visible transmittance of glazing respectively; $U-v a l u e_{B}, S H G C_{B}$ and $v t_{B}$ are the baseline of the comprehensive heat transfer coefficient of exterior walls and roof, $\mathrm{W} /\left(\mathrm{m}^{2} \cdot \mathrm{K}\right)$, the solar heat gain coefficient of glazing and the visible transmittance of glazing respectively.

If the parameters of $U$-value, SHGC or $v t$ are evaluated as non-significant, the relative weight should be 0 .

Balancing of costs and energy savings is important in energy efficiency. The optimizing goal is to find the strategy with the best energy efficiency effects and economic benefits. Because the prices of materials and structures are related to the thermal characteristics, the sensitivity coefficients have the meaning of ratio of output energy savings and costs. The economic benefits are also included in the modified sensitivity analysis. So the optimized strategy can realize the best energy efficient effect and economic benefits at the same time.

\section{Results}

In this section, the energy efficiency effects were evaluated based on the modified sensitivity analysis. The sensitivity analysis schemes for exterior walls, roof, glazing of windows and shading system have been designed based on the general applied forms. The energy consumption of each scheme has been calculated based energy consumption model in DesignBuilder. The process and results of exterior wall insulation, roof insulation, exterior windows glazing, and shading system were described in detail in Sections 3.1-3.4 respectively.

\subsection{Exterior Wall Thermal Insulations}

Extrusion polystyrene (EPS) is the most commonly applied and mature insulation system for exterior wall in China because of the reasonable price and great thermal performance such as low density and low thermal conductivity [34]. In this paper, all of the case buildings are installed with EPS 
as the exterior wall insulation material as shown in Table 2. EPS Layer is located between an inside layer of $100 \mathrm{~mm}$ concrete block and an outside layer of $100 \mathrm{~mm}$ brickwork.

In order to compare the building energy consumption simulation results of the four case buildings, the sensitivity analysis scheme of exterior wall insulation was designed. According to the practical construction experience on building envelop insulation, the U-value of common exterior wall with $120 \mathrm{~mm}$ EPS insulation can reach $0.284 \mathrm{~W} /\left(\mathrm{m}^{2} \cdot \mathrm{K}\right)$, which meets the requirements of the newest edition of design standard for energy efficiency of public buildings in China perfectly [26]. So eight levels of EPS thickness from $0 \mathrm{~mm}$ to $120 \mathrm{~mm}$ with a $20 \mathrm{~mm}$ step-length increment were applied for building model simulation. The U-values of the exterior walls with eight different EPS insulation thicknesses were from $1.932 \mathrm{~W} /\left(\mathrm{m}^{2} \cdot \mathrm{K}\right)$ with $0 \mathrm{~mm}$ to $0.284 \mathrm{~W} /\left(\mathrm{m}^{2} \cdot \mathrm{K}\right)$ with $120 \mathrm{~mm}$, as shown in Table 4 .

Table 4. Sensitivity analysis of exterior wall insulation to total energy usage intensity (EUI) of the case buildings.

\begin{tabular}{|c|c|c|c|c|}
\hline $\begin{array}{l}\text { Insulation Layer } \\
\text { Thickness (mm) }\end{array}$ & $\begin{array}{l}\text { U-Value } \\
\left(\mathrm{W} /\left(\mathrm{m}^{2} \cdot \mathrm{K}\right)\right)\end{array}$ & $\begin{array}{l}\text { HVAC EUI } \\
\left(\mathrm{kWh} /\left(\mathrm{m}^{2} \cdot \mathrm{a}\right)\right)\end{array}$ & $\begin{array}{c}\text { Total EUI } \\
\left(\mathbf{k W h} /\left(\mathrm{m}^{2} \cdot \mathbf{a}\right)\right)\end{array}$ & $\begin{array}{c}\text { Sensitivity Coefficient } \\
\text { to Total EUI }\end{array}$ \\
\hline \multicolumn{5}{|c|}{ Building in Shenyang (SC region) } \\
\hline 0 & 1.932 & 62.27 & 108.92 & 0.018550 \\
\hline 20 & 0.983 & 58.96 & 105.47 & 0.019911 \\
\hline 40 & 0.659 & 57.73 & 104.17 & 0.020317 \\
\hline 60 (base case) & 0.509 & 57.17 & 103.55 & - \\
\hline 80 & 0.397 & 56.67 & 103.04 & 0.022383 \\
\hline 100 & 0.331 & 56.39 & 102.74 & 0.022368 \\
\hline 120 & 0.284 & 56.19 & 102.52 & 0.022502 \\
\hline Average & - & - & - & 0.022326 \\
\hline \multicolumn{5}{|c|}{ Building in Tianjin (CC region) } \\
\hline 0 & 1.932 & 35.84 & 87.73 & 0.024403 \\
\hline 20 & 0.983 & 31.50 & 83.17 & 0.025967 \\
\hline 40 & 0.659 & 29.86 & 81.48 & 0.026585 \\
\hline 60 & 0.509 & 29.00 & 80.59 & 0.026656 \\
\hline 80 (base case) & 0.397 & 28.43 & 80.01 & - \\
\hline 100 & 0.331 & 28.11 & 79.70 & 0.026274 \\
\hline 120 & 0.284 & 27.85 & 79.42 & 0.027102 \\
\hline Average & - & - & - & 0.026709 \\
\hline \multicolumn{5}{|c|}{ Building in Ningbo (HS/CW region) } \\
\hline 0 & 1.932 & 37.19 & 63.35 & 0.016619 \\
\hline 20 & 0.983 & 34.16 & 60.32 & 0.017150 \\
\hline 40 & 0.659 & 33.14 & 59.30 & 0.018168 \\
\hline 60 & 0.509 & 32.53 & 58.69 & 0.017485 \\
\hline 80 & 0.397 & 32.10 & 58.26 & 0.012814 \\
\hline 100 & 0.331 & 32.08 & 58.24 & 0.034515 \\
\hline 115 (base case) & 0.295 & 31.91 & 58.00 & - \\
\hline 120 & 0.284 & 31.79 & 57.95 & 0.020410 \\
\hline Average & - & - & - & 0.019594 \\
\hline \multicolumn{5}{|c|}{ Building in Shenzhen (HS/WW region) } \\
\hline 0 & 1.932 & 72.01 & 158.26 & 0.000201 \\
\hline 10 (base case) & 1.259 & 72.02 & 158.25 & - \\
\hline 20 & 0.983 & 72.16 & 158.41 & -0.004760 \\
\hline 40 & 0.659 & 72.23 & 158.48 & -0.003110 \\
\hline 60 & 0.509 & 72.26 & 158.52 & -0.002860 \\
\hline 80 & 0.397 & 72.31 & 158.58 & -0.003070 \\
\hline 100 & 0.331 & 72.32 & 158.60 & -0.003000 \\
\hline 120 & 0.284 & 72.35 & 158.64 & -0.003170 \\
\hline Average & - & - & - & -0.002820 \\
\hline
\end{tabular}


Building energy simulation results of total energy consumption include HVAC (cooling and heating) electricity, lighting and plug electricity, driving system electricity and specific energy consumption. The influence of different U-values of exterior wall on heating, cooling, and total energy consumption was shown in Figure 3. It is obvious that the cooling energy consumption varies little with the U-values change. The largest variation of cooling EUI is only $0.34 \mathrm{kWh} /\left(\mathrm{m}^{2} \cdot \mathrm{a}\right)$, which only accounts for $0.47 \%$ of the total EUI of the building in Shenzhen. Compared with the cooling energy consumption, heating energy consumption decreases quite a few along with the reduction of U-value. The conclusion can be drawn that the impact of the U-value of the exterior wall is mainly on heating energy consumption. Except for building in Shenzhen without heating supply, the total EUIs of other three case buildings decrease as much as 5.88\%, 9.47\%, and $9.03 \%$ respectively with the exterior wall insulation thickness changing from none to $120 \mathrm{~mm}$ EPS insulation.

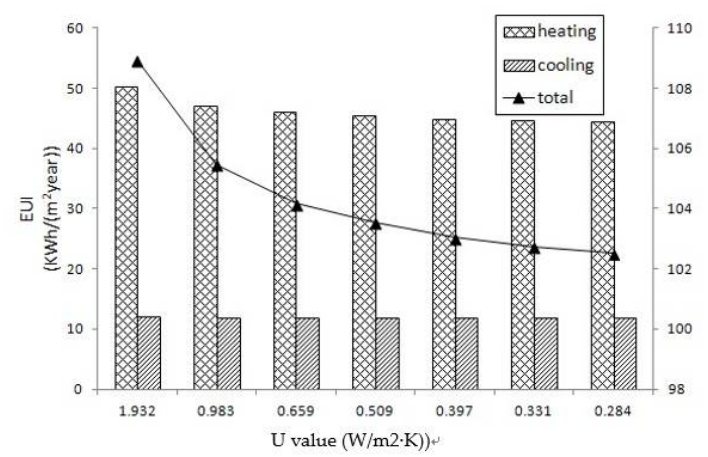

(a)

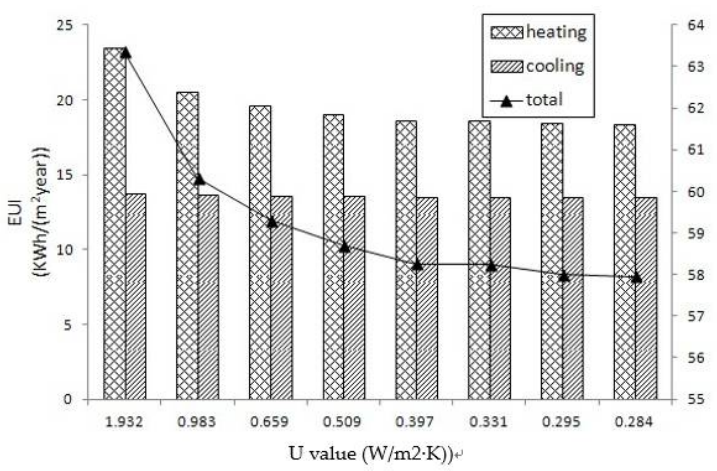

(c)

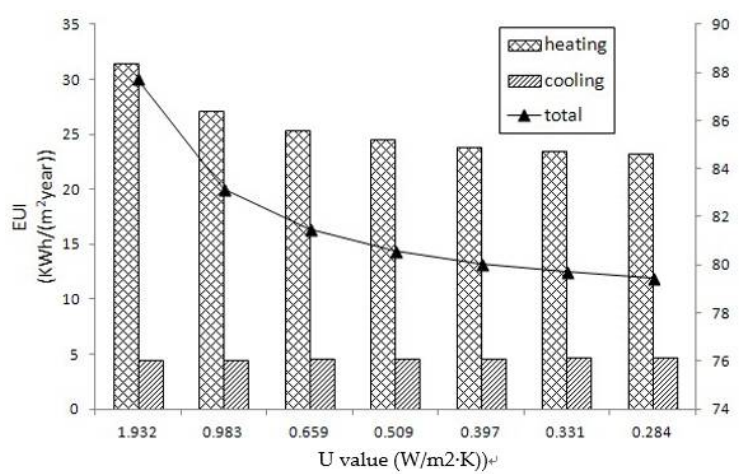

(b)

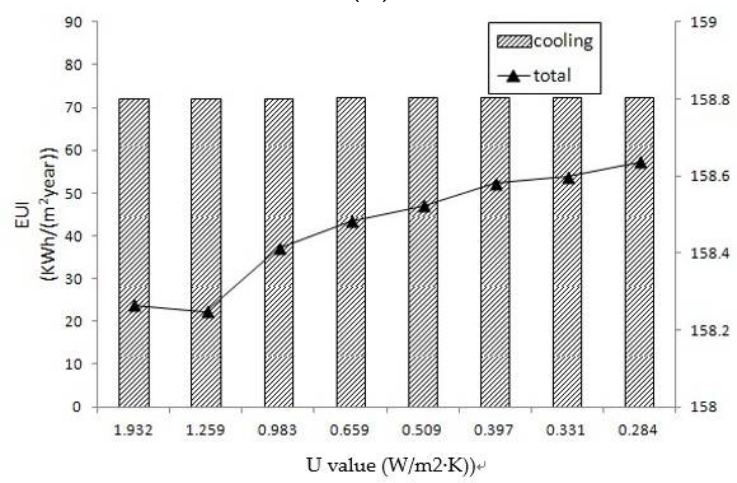

(d)

Figure 3. Influence of the U-value of exterior wall on building energy consumption. (a) Case building in Shenyang, SC region; (b) Case building in Tianjin, CC region; (c) Case building in Ningbo, HS/CW region; (d) Case building in Shenzhen, HS/WW region.

The sensitivity analysis results of the U-value of the exterior wall were shown in Table 4. The sensitivity coefficient values of buildings in Shenyang, Tianjin and Ningbo are positive, indicating that lower U-value can realize better building energy efficiency mainly by reducing HVAC energy consumption. While the sensitivity coefficient values of building Shenzhen are almost negative and the average value is $10 \%$ smaller than that of the other three buildings, which means that exterior wall insulation can slightly increase building energy consumption in HS/WW region of China. The reason is that the average outdoor air temperature is much higher than that of other climate regions, so exterior walls with lower heat transfer coefficient cannot make a great contribution to energy efficiency of the building in HS/WW region. On the other hand, the temperature difference between day and night in the HS/WW region is smaller than other climate regions in summer, so thermal insulation could enhance the thermal storage capacity of the exterior wall, which can result in a large amount of 
heat released into the room at night, leading to the increase of the cooling load as well as the cooling energy consumption.

The sensitivity coefficients, illustrated in Table 4, present stable growth trend with the increment of the exterior wall insulation thickness (reduction of the U-value). So, the level of exterior wall insulation with the largest value of sensitivity coefficient is selected as the best choice in SC region, CC region, and HS/CW region. The second primary option is $100 \mathrm{~mm}$ EPS insulation with the large change of sensitivity coefficient from that of $80 \mathrm{~mm}$ EPS insulation. As for HS/WW region, the insulation layer of $10 \mathrm{~mm}$ thickness or no insulation layer are considered better than others. So, no insulation layer is recommended in HS/WW region because of low costs.

\subsection{Roof Thermal Insulation}

All of the case buildings also selected EPS as the roof insulation material. Table 2 shows the roof insulation information of the case buildings. In order to compare the building energy consumption simulation results of the four case buildings, this paper designed the sensitivity analysis scheme of roof insulation measures. According to the practical construction experience on building envelop insulation, the U-value of roof with $200 \mathrm{~mm}$ EPS insulation is $0.177 \mathrm{~W} /\left(\mathrm{m}^{2} \cdot \mathrm{K}\right)$, which meets the requirements of the latest edition of design standard for energy efficiency of public buildings in China perfectly [26]. Six levels of EPS thickness from $0 \mathrm{~mm}$ to $200 \mathrm{~mm}$ with a $50 \mathrm{~mm}$ step-length including the thickness values of the case buildings were applied for building model simulation and the U-values of the roofs with six different EPS insulation thicknesses were from $1.546 \mathrm{~W} /\left(\mathrm{m}^{2} \cdot \mathrm{K}\right)$ with $0 \mathrm{~mm}$ to $0.177 \mathrm{~W} /\left(\mathrm{m}^{2} \cdot \mathrm{K}\right)$ with $120 \mathrm{~mm}$.

The influence of different U-values of exterior roof on heating, cooling and total energy consumption was shown in Figure 4. It is obvious that the cooling energy consumption varies little with the U-values change. Comparing with the buildings without roof insulation layer (the thickness of the roof insulation layer is $0 \mathrm{~mm}$ ), the largest energy-saving rates of the three buildings in Shenyang, Tianjin and Ningbo are $4.47 \%, 8.93 \%$ and $9.84 \%$ respectively. However, the energy consumption increases with the thickness of insulation layer in building in Shenzhen. It means that the effect of insulation is mainly to reduce heat loss during heating. When heating is not considered in warm winter regions, the insulation will result in increasing energy consumption on the contrary. The mechanism is similar to the insulation of exterior walls for buildings in HS/WW regions.

Table 5 shows the sensitivity analysis results of the U-value of the roof of the case buildings respectively. The sensitivity coefficient values of building in Shenyang, Tianjin and Ningbo are almost positive, which, similar to the exterior wall, means lower U-value can realize better building energy efficiency, mainly by reducing HVAC system energy consumption in a certain range. The rate of the sensitivity coefficient values turns rapid increasing since $135 \mathrm{~mm}$ EPS insulation in Shenyang, $100 \mathrm{~mm}$ EPS insulation in Tianjin and $135 \mathrm{~mm}$ EPS insulation in Ningbo. The corresponding U-values are inflection points. So the recommended U-value range of roof is considered to be more than $0.318 \mathrm{~W} /\left(\mathrm{m}^{2} \cdot \mathrm{K}\right)$.

While the sensitivity coefficient values of building Shenzhen are almost negative and the average value is 1-2 magnitude smaller than that of the other three buildings, indicating that roof insulation can slightly increase building energy consumption in HS/WW region of China. That is because in HS/WW region, preventing heat transfer through building roofs in summer is much more important than heat storage in winter. Combining with EUI, $30 \mathrm{~mm}$ insulation layer is recommended. The sensitivity coefficients of building in Shenyang, Tianjin, and Ningbo present stable growth trend with the increment of the roof insulation thickness (reduction of the U-value). Especially for the building in Tianjin, the sensitivity coefficients are more stable and the average value is higher than that of buildings in Shenyang and Ningbo, which means that buildings in CC region have the greatest energy efficiency contribution in the aspect of roof insulation.

Based on the above analysis, the level with the most sensitive for roof insulation layers are selected as recommended option for case buildings, $200 \mathrm{~mm}, 200 \mathrm{~mm}, 200 \mathrm{~mm}, 30 \mathrm{~mm}$ respectively. 


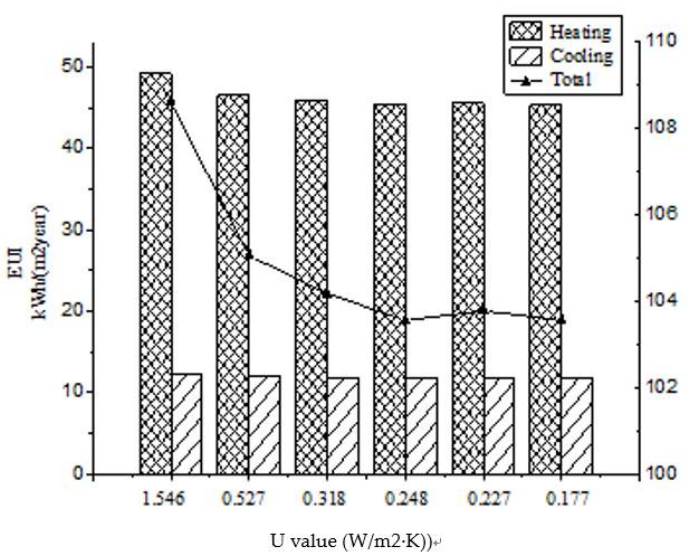

(a)

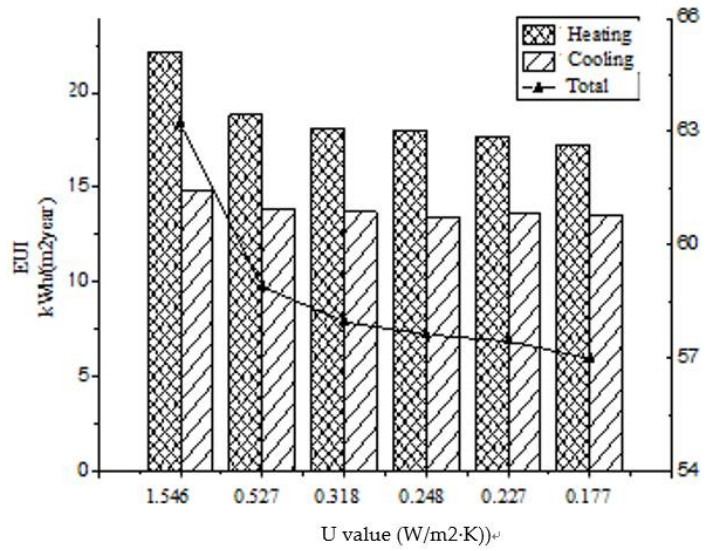

(c)

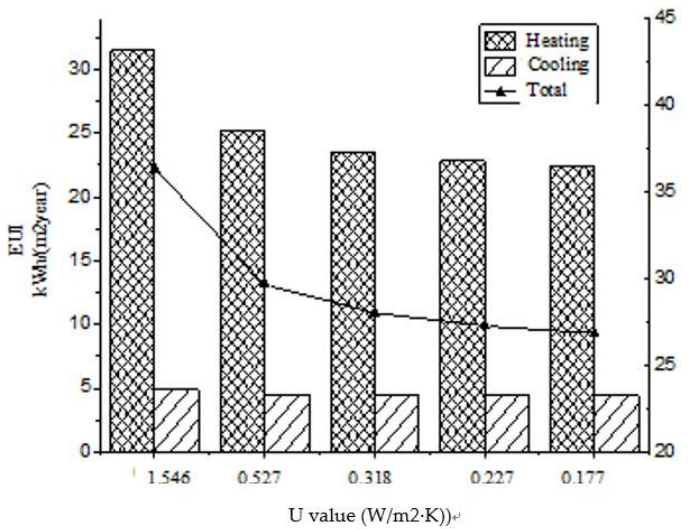

(b)

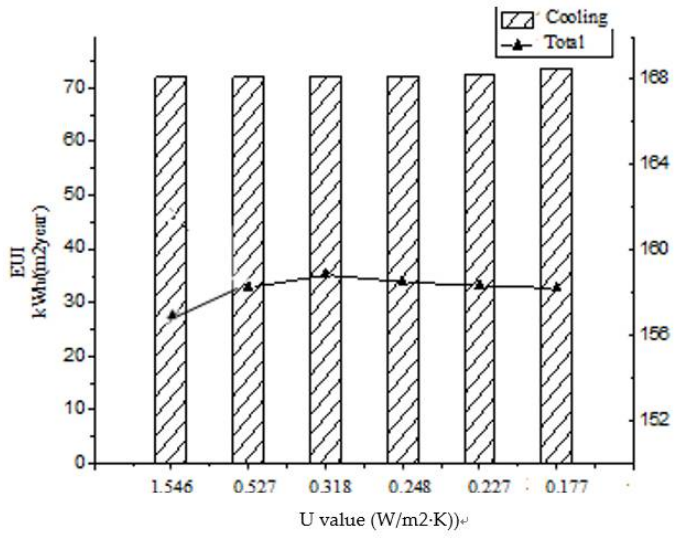

(d)

Figure 4. Influence of the U-value of roof on building energy consumption. (a) Case building in Shenyang, SC region; (b) Case building in Tianjin, CC region; (c) Case building in Ningbo, HS/CW region; (d) Case building in Shenzhen, HS/WW region.

Table 5. Sensitivity analysis of roof insulation to total EUI of the case buildings.

\begin{tabular}{|c|c|c|c|c|}
\hline $\begin{array}{l}\text { Insulation Layer } \\
\text { Thickness (mm) }\end{array}$ & $\begin{array}{c}\text { U-Value } \\
\left(\mathrm{W} /\left(\mathrm{m}^{2} \cdot \mathrm{K}\right)\right)\end{array}$ & $\begin{array}{l}\text { HVAC EUI } \\
\left(\mathrm{kWh} /\left(\mathrm{m}^{2} \cdot \mathrm{a}\right)\right)\end{array}$ & $\begin{array}{c}\text { Total EUI } \\
\left(\mathbf{k W h} /\left(\mathrm{m}^{2} \cdot \mathrm{a}\right)\right)\end{array}$ & $\begin{array}{c}\text { Sensitivity Coefficient } \\
\text { to Total EUI }\end{array}$ \\
\hline \multicolumn{5}{|c|}{ Building in Shenyang (SC region) } \\
\hline 0 & 1.546 & 61.51 & 106.31 & 0.009355 \\
\hline 50 & 0.527 & 58.50 & 105.05 & 0.012876 \\
\hline 100 & 0.318 & 57.73 & 103.78 & 0.007896 \\
\hline 135 (base case) & 0.248 & 57.39 & 103.55 & - \\
\hline 150 & 0.227 & 57.27 & 102.98 & 0.065007 \\
\hline 200 & 0.177 & 57.18 & 101.55 & 0.101196 \\
\hline Average & - & - & - & 0.039261 \\
\hline \multicolumn{5}{|c|}{ Building in Tianjin (CC region) } \\
\hline 0 & 1.546 & 35.34 & 85.71 & 0.040538 \\
\hline 50 & 0.527 & 32.64 & 83.12 & 0.054323 \\
\hline 70 (base case) & 0.42 & 30.43 & 81.12 & - \\
\hline 100 & 0.318 & 29.06 & 79.34 & 0.034660 \\
\hline 150 & 0.227 & 28.26 & 78.52 & 0.040559 \\
\hline 200 & 0.177 & 27.84 & 78.06 & 0.042139 \\
\hline Average & - & - & - & 0.042444 \\
\hline
\end{tabular}


Table 5. Cont.

\begin{tabular}{|c|c|c|c|c|}
\hline $\begin{array}{l}\text { Insulation Layer } \\
\text { Thickness (mm) }\end{array}$ & $\begin{array}{c}\text { U-Value } \\
\left(\mathrm{W} /\left(\mathrm{m}^{2} \cdot \mathrm{K}\right)\right)\end{array}$ & $\begin{array}{c}\text { HVAC EUI } \\
\left(\mathrm{kWh} /\left(\mathrm{m}^{2} \cdot \mathrm{a}\right)\right)\end{array}$ & $\begin{array}{c}\text { Total EUI } \\
\left(\mathbf{k W h} /\left(\mathrm{m}^{2} \cdot \mathbf{a}\right)\right)\end{array}$ & $\begin{array}{c}\text { Sensitivity Coefficient } \\
\text { to Total EUI }\end{array}$ \\
\hline \multicolumn{5}{|c|}{ Building in Ningbo (HS/CW region) } \\
\hline 0 & 1.546 & 36.97 & 63.20 & 0.018469 \\
\hline 50 & 0.527 & 32.66 & 58.89 & 0.019419 \\
\hline 100 & 0.318 & 31.73 & 57.95 & 0.020028 \\
\hline 135 (base case) & 0.248 & 31.40 & 57.63 & - \\
\hline 150 & 0.227 & 31.22 & 57.45 & 0.036803 \\
\hline 200 & 0.177 & 30.76 & 56.98 & 0.039084 \\
\hline Average & - & - & - & 0.026761 \\
\hline \multicolumn{5}{|c|}{ Building in Shenzhen (HS/WW region) } \\
\hline 0 & 1.546 & 71.94 & 156.66 & 0.016534 \\
\hline 30 (base case) & 0.671 & 72.02 & 158.25 & - \\
\hline 50 & 0.527 & 72.16 & 158.83 & -0.017160 \\
\hline 100 & 0.318 & 72.24 & 158.52 & -0.003180 \\
\hline 150 & 0.227 & 72.36 & 158.33 & -0.000810 \\
\hline 200 & 0.177 & 73.68 & 158.22 & 0.000271 \\
\hline Average & - & - & - & -0.000870 \\
\hline
\end{tabular}

\subsection{Glazing of Exterior Windows}

The type of glazing can influence the energy consumption of HVAC and lighting at the same time. In this analysis, the lighting was setting controlled with the indoor illuminance. The variation of total energy consumption imposed by glazing type was evaluated. Single, double and triple layer glazing types with different coating materials such as clear, reflective, Low-E, green and electrochromism were selected as glazing scheme experienced in energy consumption models [35]. In addition, the glazing layer and filling gas were also different from each other. The certain values of U-value, SHGC and visible transmittance of different glazing types were shown in Table 6.

Total EUI with different types of glazing in four case buildings were calculated and shown in Table 6. With the glazing types changing, simulation results of the four case buildings present fluctuating variation, which is different with the results of the exterior wall and roof insulation, as shown in Figure 5. So the energy efficient effects should be evaluated comprehensively. The significant level of U-value, SHGC and visible transmittance were conducted by "Weight Estimation" in SPSS 22. The results were shown in Table 7 indicates that SHGC is a significant parameter in all climate regions. U-value is significant for buildings located in Shenyang, Tianjin and Ningbo. It means that U-value and SHGC mainly influence heating and cooling energy consumption respectively. It is reasonable for the perspective of heating and cooling load formation mechanism. For SC and CC regions, heating load is much higher than cooling load because of the large difference of indoor and outdoor temperature. Solar radiation is relatively weak in cold winter regions than hot summer regions. So, the influence of $\mathrm{U}$-value turns weak while SHGC turns strong from north to south in China. Visible transmittance is not significant for all case buildings because the lighting energy consumption is relatively low comparing with heating and cooling energy consumption.

The weighted sensitivity analysis results of glazing types on total EUI of the four case buildings were calculated according to Equation (7) and shown in Tables 8 and 9. As shown in Tables 8 and 9, the tendency of weighted sensitivity coefficient in the four case buildings is different. 
Table 6. Simulation scheme of glazing type and energy consumption of case buildings.

\begin{tabular}{|c|c|c|c|c|c|c|c|c|c|}
\hline \multirow{2}{*}{ No. } & \multirow{2}{*}{ Layer } & \multirow{2}{*}{ Specification } & \multirow{2}{*}{ SHGC } & \multirow{2}{*}{$\begin{array}{l}\text { U-Value } \\
\left(\mathrm{W} / \mathrm{m}^{2} \cdot \mathrm{K}\right)\end{array}$} & \multirow{2}{*}{$\begin{array}{c}\text { Visible } \\
\text { Transmittance }\end{array}$} & \multicolumn{4}{|c|}{ Total EUI $\left(\mathrm{kWh} /\left(\mathrm{m}^{2} \cdot \mathrm{a}\right)\right)$} \\
\hline & & & & & & Shenyang & Tianjin & Ningbo & Shenzhen \\
\hline GL1 & Single & Clear & 0.810 & 6.121 & 0.898 & 102.76 & 83.32 & 63.10 & 159.31 \\
\hline GL2 & Single & Reflective & 0.235 & 5.005 & 0.080 & 108.50 & 86.93 & 68.35 & 175.65 \\
\hline GL3 & Single & Low-E & 0.710 & 4.233 & 0.811 & 101.46 & 81.53 & 59.06 & 160.07 \\
\hline GL4 & Double & Green $6 \mathrm{~mm} / 6 \mathrm{~mm}$ Air & 0.490 & 3.157 & 0.664 & 100.64 & 83.63 & 59.72 & 155.94 \\
\hline GL5 & Double & Low-E+Clear 3 mm/6 mm Air & 0.687 & 2.577 & 0.769 & 101.22 & 81.09 & 57.63 (base case) & 158.40 \\
\hline GL6 & Double & Reflective+Clear 6 mm/13 mm Air & 0.176 & 2.208 & 0.073 & 103.55 (base case) & 85.59 & 64.74 & 158.25 (base case) \\
\hline GL7 & Double & Electrochromism +Clear $6 \mathrm{~mm} / 13 \mathrm{~mm}$ Air & 0.155 & 1.772 & 0.752 & 103.66 & 85.18 (base case) & 63.21 & 158.03 \\
\hline GL8 & Triple & Low-E+Clear+Clear 3 mm/13 mm Air & 0.574 & 1.270 & 0.698 & 99.22 & 80.04 & 54.48 & 157.01 \\
\hline
\end{tabular}

Table 7. Sensitivity analysis of glazing type to total EUI of the case buildings.

\begin{tabular}{|c|c|c|c|c|c|c|c|c|c|c|c|c|}
\hline \multirow{2}{*}{$\begin{array}{c}\text { Case Building } \\
\text { Glazing Parameter }\end{array}$} & \multicolumn{3}{|c|}{ Building in Shenyang } & \multicolumn{3}{|c|}{ Building in Tianjin } & \multicolumn{3}{|c|}{ Building in Ningbo } & \multicolumn{3}{|c|}{ Building in Shenzhen } \\
\hline & U-Value & SHGC & $\begin{array}{c}\text { Visible } \\
\text { Transmittance }\end{array}$ & U-Value & SHGC & $\begin{array}{c}\text { Visible } \\
\text { Transmittance }\end{array}$ & U-Value & SHGC & $\begin{array}{c}\text { Visible } \\
\text { Transmittance }\end{array}$ & U-Value & SHGC & $\begin{array}{c}\text { Visible } \\
\text { Transmittance }\end{array}$ \\
\hline Correlation coefficient $R^{2}$ & \multicolumn{3}{|c|}{0.943} & \multicolumn{3}{|c|}{0.963} & \multicolumn{3}{|c|}{0.972} & \multicolumn{3}{|c|}{0.903} \\
\hline Standard weight & 1.116 & -0.561 & 0.169 & 0.841 & -0.858 & -0.137 & 0.875 & -0.635 & -0.247 & -0.037 & -0.888 & -0.345 \\
\hline Significance coefficient & 0.001 & 0.005 & 0.192 & 0.001 & 0.000 & 0.193 & 0.000 & 0.001 & 0.031 & 0.865 & 0.007 & 0.139 \\
\hline Significant level & $* * *$ & $* * *$ & $*$ & $* * *$ & $* * *$ & $*$ & $* * *$ & $* * *$ & $* *$ & * & $* * *$ & * \\
\hline
\end{tabular}

Note: $* * *$ respects highly significant, ${ }^{* *}$ means significant, ${ }^{*}$ indicates non-significant. 


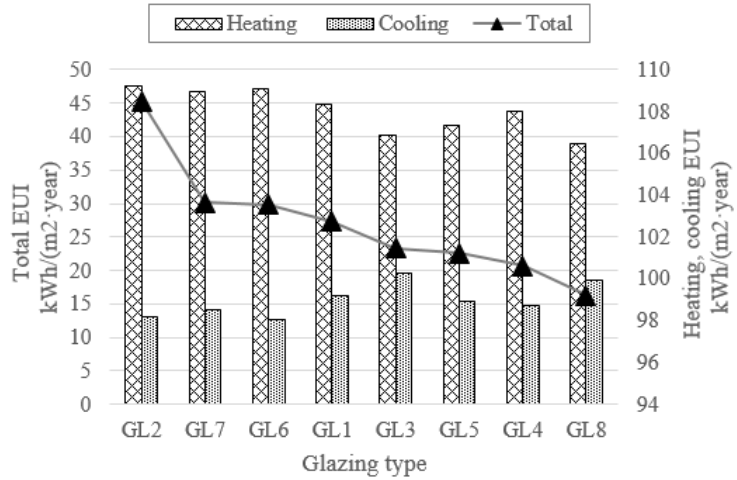

(a)

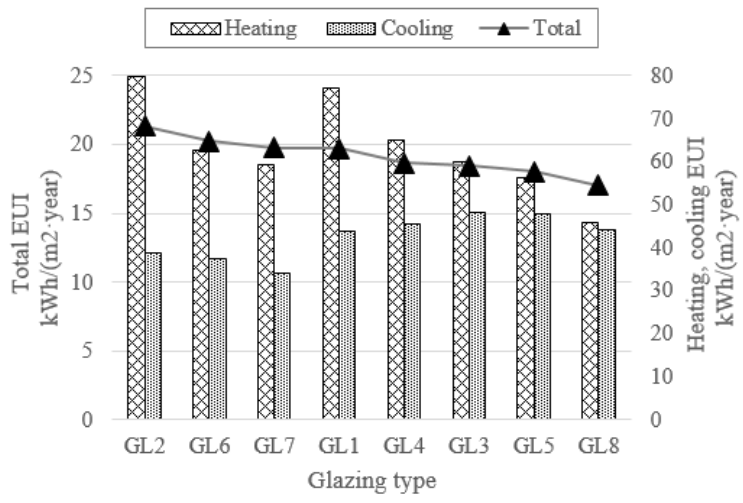

(c)

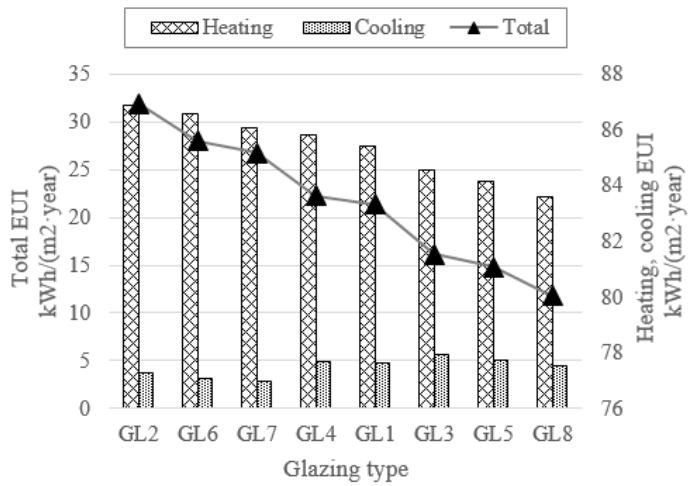

(b)

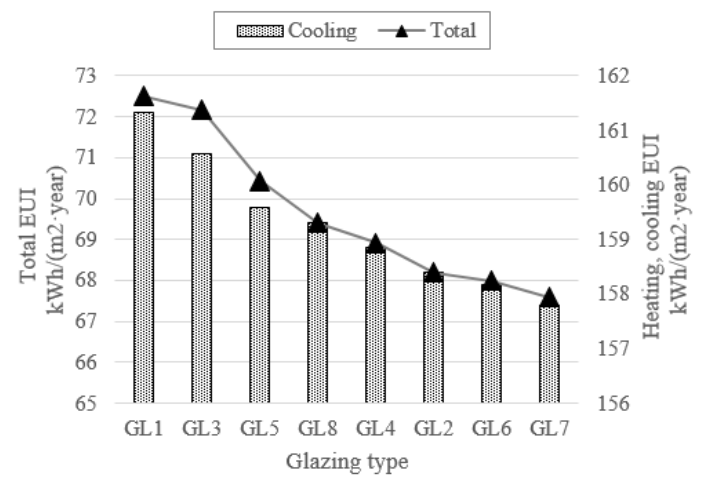

(d)

Figure 5. Influence of the glazing on building energy consumption. (a) Case building in Shenyang, SC region; (b) Case building in Tianjin, CC region; (c) Case building in Ningbo, HS/CW region; (d) Case building in Shenzhen, HS/WW region.

(1) The weighted sensitivity coefficients in Shenyang and Tianjin are generally negative, which means glazing with low U-value and high SHGC has the tendency of reducing energy consumption in cold regions. This tendency turns weak from north to south climate regions. The turning point is Ningbo with the positive weighted sensitivity coefficients of most glazing types. The weighted sensitivity coefficients are positive in Shenzhen because only SHGC is the significant parameter influencing building energy consumption of glazing. Based on the above tendency, the glazing types with the minimum negative weighted sensitivity coefficients should be considered as the best choices in the SC, CC and HS/WW regions. The glazing type with the minimum positive weighted sensitivity coefficient should be selected as the optimal one in HS/CW region.

(2) GL5 is the eligible glazing type in Shenyang and Tianjin. In Shenzhen, GL7 should be the best choice based on the weighted sensitivity coefficient. However, GL5 is more commonly used and the sensitivity coefficient of GL5 is similar with GL7. So GL5 is considered as proper too. The growth tendency of sensitivity coefficients gets faster since GL3. So the glazing type with SHGC more than 0.710 is not recommended. In Ningbo, GL3 is the best choice. So low-E glasses are proper for all regions. Because GL5 is the base case of building in Ningbo and the coefficient varies little of GL3, so GL5 can also be considered proper for buildings in Ningbo. In general, GL5, namely double glazing with $3 \mathrm{~mm}$ low-E, $3 \mathrm{~mm}$ clear and $6 \mathrm{~mm}$ air, can be considered as the best glazing type for the four climate regions. If considering costs, GL3, namely low-E glazing, can also be a good choice for HS/CW and HS/WW regions. To clarify the selecting process, the index ranges of U-value and SHGC were recommended as follows. The glazing types with the U-value more than $2.577 \mathrm{~W} /\left(\mathrm{m}^{2} \cdot \mathrm{K}\right)$ and SHGC less than 0.687 was proper for SC region and CC regions. The glazing type with SHGC between 0.490 
and 0.687 was recommended for building in HS/WW region. The glazing type with SHGC around 0.7 and U-value less than $4.233 \mathrm{~W} /\left(\mathrm{m}^{2} \cdot \mathrm{K}\right)$ was suitable for buildings in $\mathrm{HS} / \mathrm{CW}$ region.

Table 8. Sensitivity analysis of glazing type to total EUI of the case buildings in Shenyang, Tianjin and Ningbo.

\begin{tabular}{|c|c|c|c|c|c|c|}
\hline No. & $\begin{array}{c}\text { U-Value } \\
\left(\mathrm{W} /\left(\mathrm{m}^{2} \cdot \mathrm{K}\right)\right)\end{array}$ & SHGC & $\begin{array}{c}\text { Total EUI } \\
\left(\mathbf{k W h} /\left(\mathbf{m}^{2} \cdot \mathbf{a}\right)\right)\end{array}$ & $\begin{array}{c}\text { Sensitivity } \\
\text { Coefficient to } \\
\text { Total EUI (U } \\
\text { Value) }\end{array}$ & $\begin{array}{l}\text { Sensitivity } \\
\text { Coefficient to } \\
\text { Total EUI } \\
\text { (SHGC) }\end{array}$ & $\begin{array}{l}\text { Weighted } \\
\text { Sensitivity } \\
\text { Coefficient to } \\
\text { Total EUI }\end{array}$ \\
\hline \multicolumn{7}{|c|}{ Building in Shenyang (SC region) } \\
\hline GL5 & 2.577 & 0.687 & 101.22 & -0.134210 & -0.089853 & -0.119371 \\
\hline GL4 & 3.157 & 0.490 & 100.64 & -0.065400 & -0.080502 & -0.070452 \\
\hline GL3 & 4.233 & 0.710 & 101.46 & -0.021960 & -0.083099 & -0.042413 \\
\hline GL1 & 6.121 & 0.810 & 102.76 & -0.004290 & -0.035381 & -0.014691 \\
\hline GL7 & 1.772 & 0.155 & 103.66 & -0.00566 & 0.000935 & -0.003454 \\
\hline GL6 (base case) & 2.208 & 0.176 & 103.55 & - & - & - \\
\hline GL8 & 1.270 & 0.574 & 99.22 & 0.098368 & -0.142327 & 0.017849 \\
\hline GL2 & 5.005 & 0.235 & 108.50 & 0.037802 & 0.060916 & 0.045534 \\
\hline \multicolumn{4}{|c|}{ Average } & -0.013620 & -0.052759 & -0.026714 \\
\hline \multicolumn{7}{|c|}{ Building in Tianjin (CC region) } \\
\hline GL5 & 2.577 & 0.687 & 81.09 & -0.105640 & -0.223553 & -0.165186 \\
\hline GL3 & 4.233 & 0.710 & 81.53 & -0.030840 & -0.205070 & -0.118827 \\
\hline GL8 & 1.270 & 0.574 & 80.04 & 0.105335 & -0.237813 & -0.067956 \\
\hline GL1 & 6.121 & 0.810 & 83.32 & -0.00886 & -0.116659 & -0.063299 \\
\hline GL4 & 3.157 & 0.490 & 83.63 & -0.023260 & -0.058591 & -0.041102 \\
\hline GL7 (base case) & 1.772 & 0.155 & 85.18 & - & - & - \\
\hline GL6 & 2.208 & 0.176 & 85.59 & 0.019511 & 0.005439 & 0.012405 \\
\hline GL2 & 5.005 & 0.235 & 86.93 & 0.011293 & 0.030521 & 0.021003 \\
\hline \multicolumn{4}{|c|}{ Average } & -0.004640 & -0.100716 & -0.060423 \\
\hline \multicolumn{7}{|c|}{ Building in Ningbo (HS/CW region) } \\
\hline GL6 & 2.208 & 0.176 & 64.74 & -0.862110 & 0.028135 & -0.487735 \\
\hline GL7 & 1.772 & 0.155 & 63.21 & -0.310460 & 0.019917 & -0.171527 \\
\hline GL5 (base case) & 2.577 & 0.687 & 57.63 & - & - & - \\
\hline GL3 & 4.233 & 0.710 & 59.06 & 0.038679 & 0.025023 & 0.032936 \\
\hline GL8 & 1.270 & 0.574 & 54.48 & 0.107770 & -0.048309 & 0.042134 \\
\hline GL1 & 6.121 & 0.810 & 63.10 & 0.069086 & 0.102208 & 0.083015 \\
\hline GL4 & 3.157 & 0.490 & 59.72 & 0.161360 & 0.024961 & 0.104000 \\
\hline GL2 & 5.005 & 0.235 & 68.35 & 0.197405 & 0.053650 & 0.136952 \\
\hline \multicolumn{4}{|c|}{ Average } & -0.085470 & 0.025698 & -0.037175 \\
\hline
\end{tabular}

Table 9. Sensitivity analysis of glazing type to total EUI of the case building in Shenzhen, HS/WW region.

\begin{tabular}{ccccc}
\hline No. & SHGC & $\begin{array}{c}\text { Total EUI } \\
\left(\mathbf{k W h} /\left(\mathbf{m}^{2} \cdot \mathbf{a}\right)\right)\end{array}$ & $\begin{array}{c}\text { Sensitivity Coefficient } \\
\text { to Total EUI (SHGC) }\end{array}$ & $\begin{array}{c}\text { Weighted Sensitivity } \\
\text { Coefficient to Total EUI }\end{array}$ \\
\hline GL1 & 0.81 & 161.63 & 0.005805 & 0.005805 \\
GL3 & 0.71 & 161.37 & 0.006372 & 0.006372 \\
GL4 & 0.49 & 158.94 & 0.002933 & 0.002933 \\
GL2 & 0.235 & 158.4 & 0.002825 & 0.002825 \\
GL8 & 0.574 & 159.31 & 0.002442 & 0.002442 \\
GL5 & 0.687 & 160.07 & 0.001916 & 0.001916 \\
GL7 & 0.155 & 157.94 & 0.001645 & 0.016450 \\
GL6 (base case) & 0.176 & 158.25 & - & - \\
& Average & & 0.005821 & 0.005821 \\
\hline
\end{tabular}

\subsection{Shading System}

The most commonly used shading systems are fixed shading systems, so movable shading systems, as well as artificial regulations, are not considered in this paper. Traditional fixed shading 
system includes interior shading and exterior shading, generally diffusing blinds, overhanging board, and louver respectively. Shading system can reasonably prevent sunlight shining through the windows. Overall shading coefficient (OSC) is the main parameter to describe the shading effect of shading system and windows [26]. Buildings with lower OSC usually obtain less radiant heat. So the energy efficient effect of shading system is a balancing problem [36]. Research has demonstrated the fact that shading system can effectively reduce cooling energy consumption in summer [37,38]. However, the influence of shading system on heating energy consumption in winter was seldom studied. In fact, the lighting energy consumption is also influenced by the shading system. In this paper, six levels of simulation schemes including no shading system, interior shading, and exterior shading system were proposed to discuss the influence of different shading systems on total energy consumption, including heating and cooling energy consumption and lighting energy consumption. OSC is the multiplication of shading coefficient of glasses and exterior shading coefficient of building (SD). The glass of double layer with $3 \mathrm{~mm}$ low-E, $3 \mathrm{~mm}$ clear and $6 \mathrm{~mm}$ air has been proved as the best in Section 3.3. So in this section, this type of glazing, with the shading coefficient of 0.52 , were adopted in simulation. OSC for each type of shading was shown in Table 10. The occupant usage pattern of the interior shading is extremely complex and random [39,40]. So the usage rate was assumed as 1 in the simulation of WS2-WS7.

Table 10 shows the detail information of the 7 shading combination forms from no shading to long length of overhanging board and louver of exterior shading. The sizes of horizontal overhanging board and louver altered in each level in order to accurately test the influence on building energy consumption. The energy consumption simulation results are shown in Figure 6.

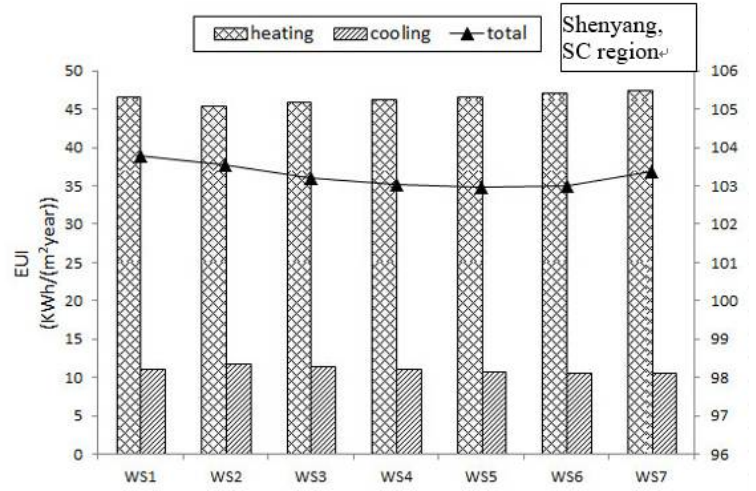

(a)

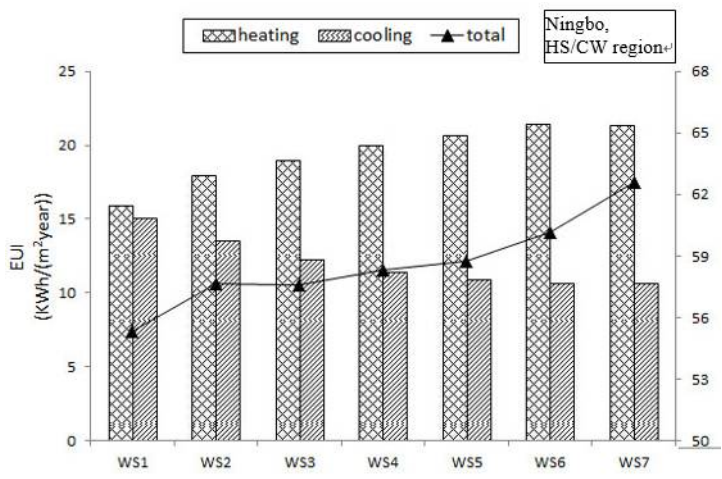

(c)

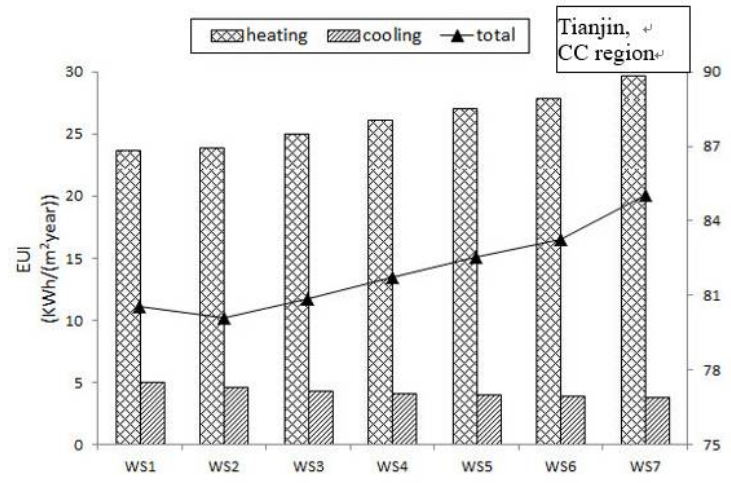

(b)

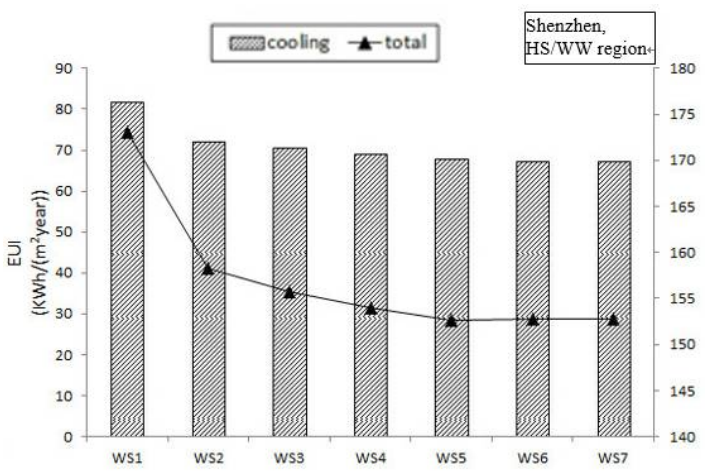

(d)

Figure 6. Influence of shading types on total energy consumption. (a) Case building in Shenyang, SC region; (b) Case building in Tianjin, CC region; (c) Case building in Ningbo, HS/CW region; (d) Case building in Shenzhen, HS/WW region. 
Table 10. Simulation scheme of shading system.

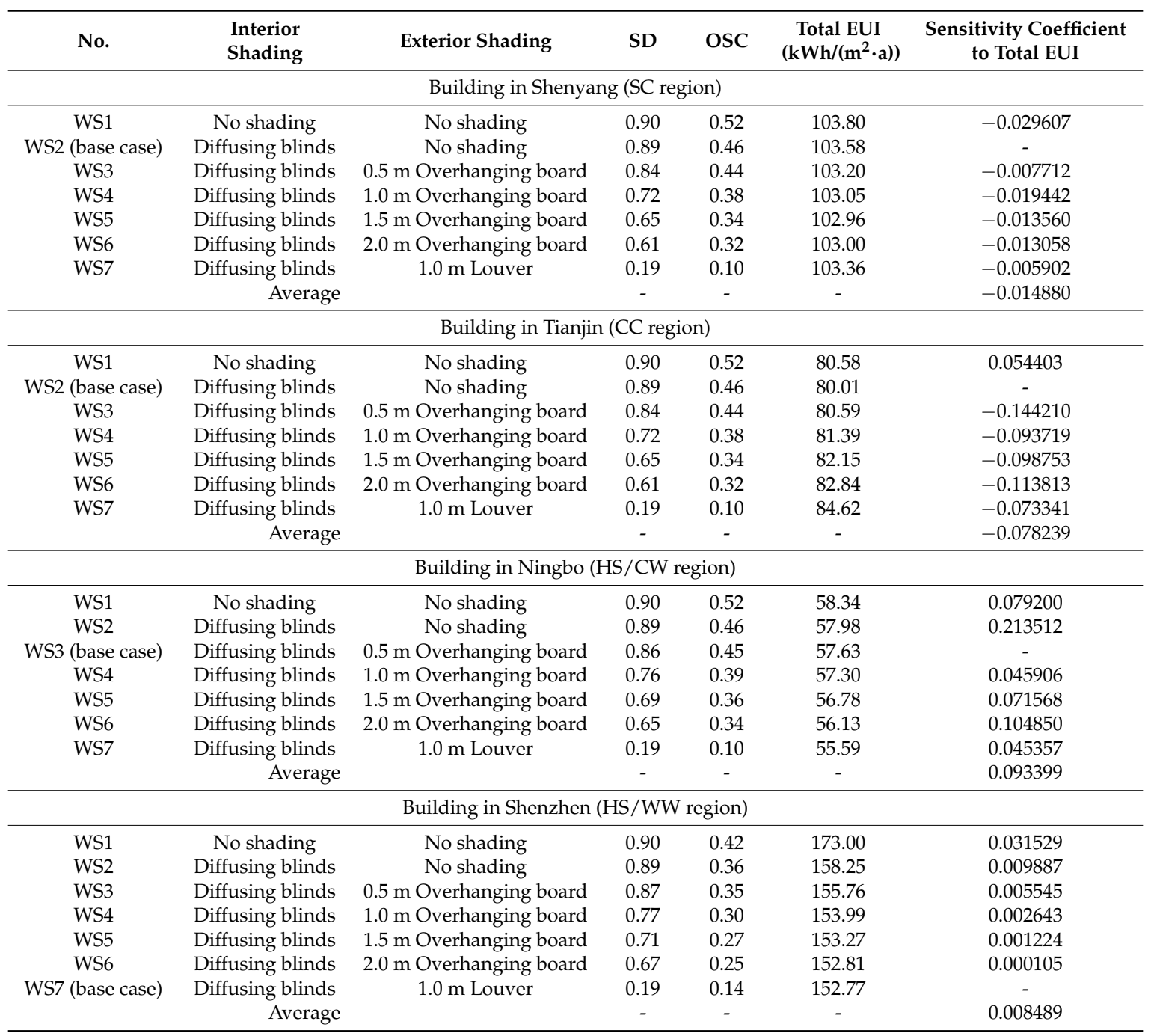

Comparing no exterior shading system of WS1 with the basic shading of WS2, cooling energy consumption can be reduced by $0.99 \%, 16 \%, 18.55 \%$ and $13.78 \%$ respectively while the heating consumption increasing by $5.68 \%, 19.54 \%$ and $12.06 \%$ for buildings in Shenyang, Tianjin and Ningbo. The total energy consumption in a whole year of the case buildings presents approximate linear distributions with the length increment of the overhanging board. Comparing with louver shading of WS6, overhang shading of WS3 with the same length of overhanging board can reduce the annual total energy consumption by $3.82 \%$ and $6.86 \%$ respectively in the building in Tianjin and Ningbo. While for building in Shenzhen, louver shading performs better energy-saving effect than the overhanging board shading.

The sensitivity coefficients of shading systems to EUI are calculated in Table 9. The variation trends of four case buildings are quite different. This is because the base cases are at different levels. For building in Shenyang, the base case is diffusing blinds of interior shading. The sensitivity coefficient of Shenyang is negative; however, it changes from positive to negative in Tianjin. This means, in Shenyang, the high level of shading system cannot make better effects on energy efficiency and no shading is the best choice. In Tianjin, only the value of WS1 is positive and the absolute values of negative ones tend smaller. This means a high level of shading can just make limited effects on energy efficiency. So, the base case is the best choice. The sensitivity coefficients of building in Ningbo and Shenzhen are positive. This means for buildings in hot summer climate regions, the high-level shading 
system tends to make the energy consumption lower. So WS6 with the largest sensitivity coefficient is the best choice. As for building in Shenzhen, the value of sensitivity coefficient is almost positive because the base case is WS7. So, the base case is recommended. It means that OSC is recommended to be less than 0.35 in hot summer regions.

From the systemic view, the sensitivity of buildings in Shenyang and Tianjin are generally negative and data of Ningbo and Shenzhen is positive. This means that the energy efficient effect of shading system in Ningbo and Shenzhen is more significant than in Shenyang and Tianjin. So the shading system in hot summer regions, especially HT/WW region, is essential.

\section{Priority Ranking and Optimum Energy Efficiency Strategy of PEEEMS}

The principle of building energy efficiency for PEEEMs is to prevent heat losing during heating and reducing heat gain while cooling. Because the various exterior climate conditions, the emphasis of the thermal performance of building envelop should be different. So the solutions of PEEEMs must be optimized depending on climate. The optimizing goal is to find the strategy with the best energy-saving effects and economic benefits simultaneously.

According to the results of sensitivity analysis above, the optimum building envelop energy efficiency strategies can be proposed for the four case buildings, as shown in Table 11. The effects of the four kinds of PEEEMs on building energy consumption were analyzed separately. The optimized strategies with the average values of sensitivity coefficients were summarized.

Table 11. Optimum strategy of passive envelop energy efficient measures (PEEEMs) of the case buildings.

\begin{tabular}{|c|c|c|c|c|c|}
\hline PEEEM & Index & $\begin{array}{l}\text { Building in } \\
\text { Shenyang, SC } \\
\text { Region }\end{array}$ & $\begin{array}{l}\text { Building in } \\
\text { Tianjin, CC } \\
\text { Region }\end{array}$ & $\begin{array}{l}\text { Building in Ningbo, } \\
\text { HS/CW Region }\end{array}$ & $\begin{array}{c}\text { Building in } \\
\text { Shenzhen, HS/WW } \\
\text { Region }\end{array}$ \\
\hline $\begin{array}{l}\text { Exterior } \\
\text { wall }\end{array}$ & U-value $\left(\mathrm{W} /\left(\mathrm{m}^{2} \cdot \mathrm{K}\right)\right)$ & 0.284 & 0.284 & 0.331 & 1.932 \\
\hline \multirow{4}{*}{ Roof } & Type & $200 \mathrm{~mm}$ EPS & $200 \mathrm{~mm}$ EPS & $200 \mathrm{~mm}$ EPS & $30 \mathrm{~mm}$ EPS \\
\hline & U-value $\left(\mathrm{W} /\left(\mathrm{m}^{2} \cdot \mathrm{K}\right)\right)$ & 0.177 & 0.177 & 0.177 & 0.671 \\
\hline & Energy efficiency rate (\%) & 7.03 & 34.84 & 16.8 & - \\
\hline & Sensitivity coefficient & 0.101196 & 0.042139 & 0.039084 & - \\
\hline \multirow{6}{*}{ Glazing } & U-value $\left(\mathrm{W} /\left(\mathrm{m}^{2} \cdot \mathrm{K}\right)\right)$ & 0.687 & 0.687 & $0.574 / 4.233$ & 0.687 \\
\hline & SHGC & 4.233 & 4.233 & $1.270 / 0.710$ & 4.233 \\
\hline & Visible transmittance & 0.769 & 0.769 & $0.698 / 0.811$ & 0.769 \\
\hline & $\begin{array}{c}\text { Sensitivity coefficient } \\
\text { (U-value) }\end{array}$ & -0.134210 & -0.105640 & $-/ 0.038679$ & - \\
\hline & $\begin{array}{c}\text { Sensitivity coefficient } \\
\text { (SHGC) }\end{array}$ & -0.089853 & -0.223553 & $-/ 0.025023$ & -0.507640 \\
\hline & $\begin{array}{l}\text { Weighted sensitivity } \\
\text { coefficient }\end{array}$ & -0.119371 & -0.165186 & $-/ 0.032936$ & -0.507640 \\
\hline
\end{tabular}


As shown in Table 11, the following conclusions can be drawn.

(1) PEEEMs priority rankings for the climate regions.

Based on the sensitivity analysis results and energy efficiency rate of the optimized exterior wall insulation, roof insulation, glazing type of different SHGC \& U-value and the influence of shading system on total energy consumption, the application priority rankings for buildings in each climate regions were concluded as follows.

- Buildings in SC region: Exterior wall insulation > roof insulation > glazing; Shading is not recommended.

- Buildings in CC region: Roof insulation > exterior wall insulation > glazing > shading system.

- Buildings in HS/CW region: Glazing > roof insulation > exterior wall insulation > shading system.

- Buildings in HS/WW region: Shading system > glazing. Insulation is not recommended.

The recommended ranges of the thermal performance properties of PEEEMs were listed in Table 12.

Table 12. Recommended ranges of the thermal performance properties of PEEEMs.

\begin{tabular}{cccccc}
\hline PEEEMs & $\begin{array}{c}\text { Thermal Performance } \\
\text { Property }\end{array}$ & $\begin{array}{c}\text { Buildings in } \\
\text { SC Region }\end{array}$ & $\begin{array}{c}\text { Buildings in } \\
\text { CC Region }\end{array}$ & $\begin{array}{c}\text { Buildings in } \\
\text { HS/CW Region }\end{array}$ & $\begin{array}{c}\text { Buildings in } \\
\text { HS/WW Region }\end{array}$ \\
\hline Exterior walls & U-value $\left(\mathrm{W} /\left(\mathrm{m}^{2} \cdot \mathrm{K}\right)\right)$ & $\leq 0.331$ & $\leq 0.331$ & $\leq 0.331$ & - \\
Roof & U-value $\left(\mathrm{W} /\left(\mathrm{m}^{2} \cdot \mathrm{K}\right)\right)$ & $\leq 0.318$ & $\leq 0.318$ & $\leq 0.318$ & - \\
Glazing type & U-value $\left(\mathrm{W} /\left(\mathrm{m}^{2} \cdot \mathrm{K}\right)\right)$ & $\leq 2.577$ & $\leq 2.577$ & $\leq 4.233$ & - \\
Shading system & SHGC & $\leq 0.687$ & $\leq 0.687$ & Around 0.7 & $\leq 0.687$ \\
\hline
\end{tabular}

The high energy-saving rates demonstrated that the thermal insulation technology of exterior walls or roof can both fairly realize effective application results on reducing building energy consumption in climate regions which need heating supply. Based on the sensitivity coefficient of PEEEMs shown in Table 10, the sensitivity coefficients of roof insulation is higher than that of exterior wall for buildings in Shenyang and Tianjin. Especially in Shenyang, the sensitivity coefficient of roof insulation is 4 times more than that of exterior wall. So the insulation of roof is more important than exterior wall for building in Shenyang and Tianjin.

In Ningbo, the sensitivity coefficient is almost equal of insulation of exterior walls and roof. The weighted sensitivity coefficient of the second optimized glazing is equal with insulation of exterior walls and roof. As the best strategy of exterior walls has already been applied in base case, the glazing of exterior windows is considered to be more significant than exterior walls and roof.

In Shenzhen, glazing and shading should be put more emphasis on than other PEEEMs because the sensitivity is much prominent, especially shading. Insulation of exterior walls and roof is not recommended because it would increase building energy consumption on the contrary.

(2) The energy efficiency rate of optimum strategies.

Monthly energy consumption comparisons for the four case buildings were calculated and shown in Figure 7. The energy efficiency rate of case buildings between the initial and the optimum building envelop energy efficiency strategies are various with the four cases.

As illustrated in the figure, the energy consumption of the optimum strategies of case buildings is various for the four cases, from $7.75 \%$ (Tianjin) to $20.87 \%$ (Ningbo). The energy efficiency rates are much depended on the initial condition of case buildings. Three kinds of situations were involved in the optimum strategy. Firstly, if the key PEEEMs adopted in the case buildings are as good as the recommended ones, the original measures will be reserved in energy efficiency evaluation simulation, thus resulting in relatively low energy efficiency rate. Such as the case of Shenzhen, because the inside shading of diffusing blinds and the outside shading with $1.0 \mathrm{~m}$ louver have been applied in case building, the energy efficiency rate will not be higher than that of Ningbo. Secondly, the optimum 
strategies were partially adopted in the base case. In Ningbo, the sensitivity coefficients of the insulation of exterior walls and roof are almost equal. The optimum of exterior walls has been set as the best strategy, however, the slight changing of roof insulation from $135 \mathrm{~mm}$ to $200 \mathrm{~mm}$ results in more than $20 \%$ energy efficiency rate. Thirdly, the changing rates of optimum strategies are different for cases. When optimizing the roof insulation from $135 \mathrm{~mm}$ to $200 \mathrm{~mm}$, the energy efficiency rate of nearly $10 \%$ has been achieved comparing with the case building in Tianjin, even though the roof insulation is optimized from $70 \mathrm{~mm}$ to $120 \mathrm{~mm}$ while other optimizing is similar. In addition, the outdoor temperature in Tianjin is lower than that of Shenyang, so the similar PEEEM in Tianjin will get less energy efficiency.

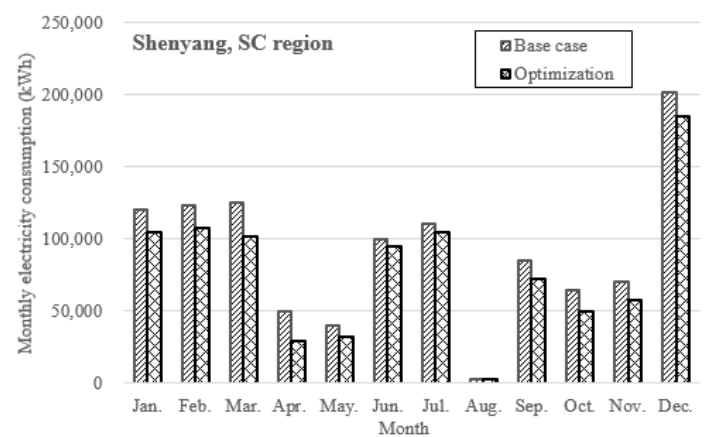

(a)

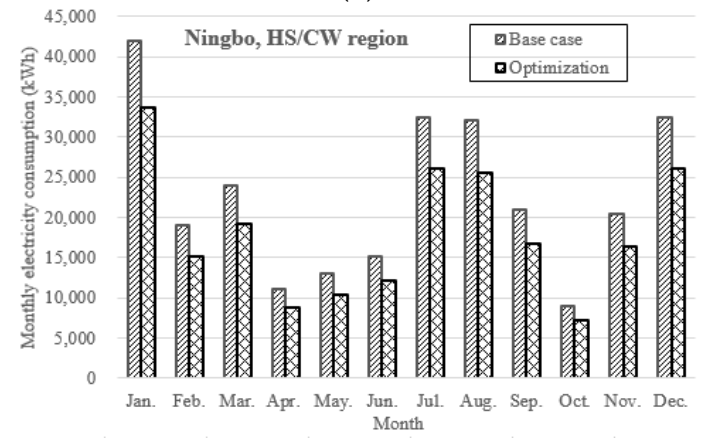

(c)

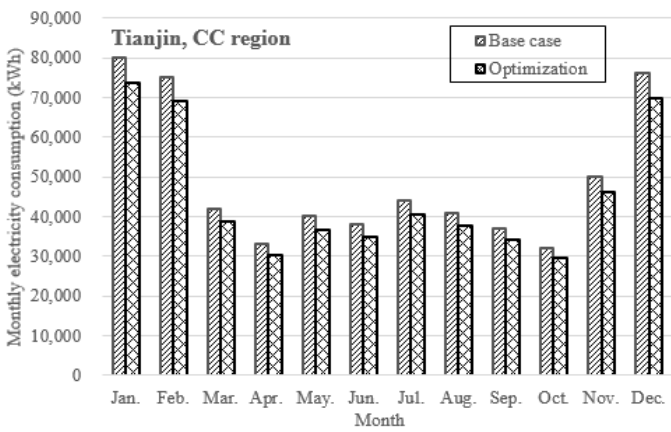

(b)

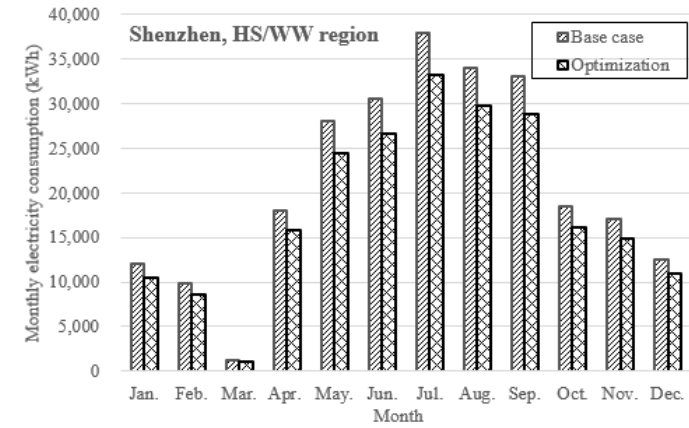

(d)

Figure 7. Energy consumption comparisons between the initial and optimum strategies of the case buildings. (a) Case building in Shenyang, SC region; (b) Case building in Tianjin, CC region; (c) Case building in Ningbo, HS/CW region; (d) Case building in Shenzhen, HS/WW region.

\section{Discussion}

\subsection{Theoretical Economic Benefits}

The price of PEEEMs varies with not only material, manufacturing technique but also location, transportation, brand et al. So, the price of each PEEEM is difficult to be estimated. However, it is certain that the price is always positive corrected with operation performance for mature technologies. So, the economic elements are also considered involving in the input parameters in sensitivity analysis.

To verify the economic benefit of the optimum energy efficiency strategies in the design stage, the theoretical payback periods of each case building were calculated by Equation (8).

$$
P_{t}=\frac{\text { Saving energy fee }}{\text { Incremental investment }}=\frac{\left(E U I_{o p}-E U I_{b}\right) \times F_{a e}}{I_{o p}-I_{b}}
$$

where $P_{t}$ is the theoretical payback period, $\mathrm{h} ; E U I_{o p}$ is the energy consumption with optimum strategies, $\mathrm{kWh} / \mathrm{m}^{2} ; F_{a e}$ is the average electricity price, $\mathrm{RMB} / \mathrm{kWh} ; I_{o p}$ is the cost of optimum strategies in design stage, RMB; $I_{b}$ is the initial cost of case building, RMB. 
The incremental costs are the increasing investments of the optimum strategies on the basis of the initial strategy in design stage. They are theoretical values aiming at evaluating the feasibility of optimized strategies in design stage instead of energy efficiency retrofit. So the costs of construction and labor are similar with initial strategies. The incremental costs are mainly material fee. Same brands for each PEEEM were selected. The economic benefits calculation is shown in Table 13.

Table 13. Economic benefits analysis of the case buildings.

\begin{tabular}{ccccc}
\hline Building & $\begin{array}{c}\text { Building in } \\
\text { Shenyang }\end{array}$ & $\begin{array}{c}\text { Building in } \\
\text { Tianjin }\end{array}$ & $\begin{array}{c}\text { Building in } \\
\text { Ningbo }\end{array}$ & $\begin{array}{c}\text { Building in } \\
\text { Shenzhen }\end{array}$ \\
\hline Energy consumption of initial strategy $\left(\mathrm{kWh} / \mathrm{m}^{2}\right)$ & 103.55 & 80.01 & 57.63 & 158.25 \\
Energy consumption of optimum strategy $\left(\mathrm{kWh} / \mathrm{m}^{2}\right)$ & 93.77 & 73.81 & 45.60 & 137.24 \\
Energy-saving rate $(\%)$ & 9.44 & 7.75 & 20.87 & 13.27 \\
Average electricity price $(\mathrm{RMB} / \mathrm{kWh})$ & 0.8068 & 0.9925 & 0.8929 & 0.8512 \\
Incremental investment $\left(\mathrm{RMB} / \mathrm{m}^{2}\right)$ & 8.70 & 4.24 & 15.60 & 1.87 \\
Insulation of exterior walls (RMB per insulation area) & 45 & 30 & 0 & 0 \\
Insulation of roof (RMB per insulation area) & 0 & 0 & 65 & 0 \\
Glazing of exterior windows (RMB per window area) & 30 & 30 & 0 & 30 \\
Shading (RMB per shading material area) & 0 & 0 & 40 & 0 \\
Theoretical payback period (year) & 1.10 & 0.69 & 1.45 & 0.10 \\
\hline
\end{tabular}

As shown in Table 13, the payback period is no more than 1.5 years if the measures had been improved during design stage for new buildings. Because the dismantling and reconstruction fee were not included in costs, the theoretical payback period is extremely shorter than that of traditional energy efficient retrofit. Certainly, the factors of building models and the initial envelope system of the case buildings both influence the value of energy-saving rate. The aim to calculate the theoretical payback periods is to demonstrate that the optimized PEEEMs can be in favor of building energy efficiency and economic benefit at the same time. It can be proved that the sensitive analysis combined with building energy consumption simulation tool is a suitable method for evaluating the energy efficiency effects of PEEEMs during building design stage.

\subsection{Indoor Thermal Comfort}

Except for economic benefits, the indoor thermal comfort is also taken as an important factor in building energy efficiency. Two kinds of patterns are widely used in dealing with indoor thermal comfort. One is considering the comfortable indoor environment as a necessary condition in energy efficient buildings, such as the above articles. The other is taking the indoor air quality as an influencing factor of building energy consumption and exploring the quantification relationship. Salvalai G. et al. [41] assessed different cooling concept of cooling in six European climate zones by carrying out dynamic simulations in Trnsys 17. Cooling technologies, including natural ventilation, mechanical night ventilation, fan-coils, suspended ceiling panels and concrete core conditioning, were evaluated from the aspects of indoor thermal comfort and energy consumption. Pfafferott J. et al. [42] adopted Monte-Carlo simulation and significance analysis to calculate the night ventilation effects on indoor temperature. Comparing the two kinds of research, most articles in the second kind is related to natural ventilation. This is because the effect of natural ventilation greatly relies on the outdoor climate condition and architecture design of building shape, spatial organization et al. The effects may be various. So the variety must be limited in the comfort range of indoor environment.

The topic of this research generally related to the first kind. Certain values shown in Table 2 of indoor air temperature were designed in case buildings. Thus, the simulation results of DesignBuilder models are under the condition of $26^{\circ} \mathrm{C}$ in summer and $20^{\circ} \mathrm{C}$ in winter, which can satisfy the comfort environment of PMV $= \pm 0.5, \mathrm{PPD} \leq 20 \%$. 


\subsection{Other Passive Building Energy Efficient Measures}

Architecture design is another hot topic in building energy efficiency design recently. Xie X. and Gou Z. [43] proposed an integrated design process involving building architecture design and building performance. Early intervention and late verification methods were established to solve the energy performance simulation problems for architects. Friess W. A. and Rakhshan K. [44] reviewed the passive envelop measures in the hot climate regions from the aspects of building orientation and layout, wall and roof, windows and natural ventilation and estimated the energy efficiency potential for each aspect. However, the exact optimum parameters were not proposed for those measures.

This paper focuses on the thermal performance of building envelop, which generally refers to insulation of exterior walls, windows and roof and solar radiation rejection. Sensitivity analysis was proved to be the proper method for addressing the quantification problems between building energy efficient effects and economic benefits. As for other passive building energy efficient measures, building shape, natural ventilation for example, it is difficult to propose an index to represent energy performance characteristics and price at the same time. Other methods should be explored, CFD for example. Based on the controllable, quantifiable and optimizable selection principle for variables, such kinds of passive building energy efficient measures were not discussed in this paper.

The results in this study are applicable for multi-story, mid-rise buildings with relatively small and medium sizes and regular shape. Super high, large buildings or bizarre shape buildings will need pointedly and further research. The research conclusions can provide case references and technical recommendations for building energy efficiency engineers to optimize the design schemes based on relative building energy efficiency standards. In addition, local design standards can be adequately improved based on the national standards. The priority order this paper proposed can make reference for the selection of indexes to be improved. For example, for cities in SC region, insulation of exterior walls should be optimized rather than shading, while shading should be optimized for cities in HS/WW region and insulation is not recommended.

\section{Conclusions}

In this paper, the modified sensitivity analysis based on building energy simulation was conducted to evaluate the energy-saving effect of PEEEMs in severe cold, cold, hot summer and cold winter, hot summer and warm winter climate regions in China. Four case buildings located in Shenyang, Tianjin, Ningbo and Shenzhen, typical cities representing the severe cold (SC) region, cold (CC) region, hot summer and cold winter (HS/CW) region, and hot summer and warm winter (HS/WW) region in China respectively, were selected. The energy-saving effects of different building envelope strategies including exterior wall insulation, roof insulation, glazing, and shading system on building energy consumption were calculated and analyzed based on the modified sensitivity analysis. This paper focuses on the energy-saving and economic effects of PEEEMs in design stage and conclusions were drawn and summarized as follows:

(1) An effective method for the research on PEEEMs in different climate regions of China was provided. Building energy simulation of single PEEEM cooperating with sensitivity analysis with comprehensive heat transfer coefficient (U-value), the solar heat gain coefficient (SHGC) and overall shading coefficient (OSC) on building energy consumption has been proved as a reliable approach for building energy efficiency research. U-value and OSC were the characteristic parameters describing the thermal performance of insulation of exterior walls, roof and shading system respectively. As for glazing of exterior windows, U-value and SHGC were both significant parameters for buildings in SC, $\mathrm{CC}$ and $\mathrm{HS} / \mathrm{CW}$ regions while $\mathrm{U}$-value is not significant in HS/WW regions.

(2) Based on the values of weighted sensitivity coefficient of exterior wall thermal insulation, roof thermal insulation, glazing type of different SHGC \& U-value and shading system to total energy consumption, the application priority rankings for buildings in each climate regions were summarized. The thermal insulation of exterior walls and roof were considered to be the most important measures in SC regions and CC regions respectively. As for regions with hot summer, shading and glazing 
were more important than insulation. In hot summer and cold winter regions, glazing was the most significant measure while shading was the key measure in hot summer and warm winter regions. The recommended ranges of the thermal performance properties of PEEEMs were also proposed. Both the priority orders and the recommended ranges of thermal performance properties can be adopted for designers to optimize the design scheme on the base of relative standards. Similarly, relative standards can be improved based on the priority order.

(3) According to the best value of PEEEM parameters based on the results of sensitivity analysis results, the optimum energy efficiency strategies were proposed for the four case buildings in different climate regions of China. The energy efficiency rates of $9.44 \%$ (Shenyang, SC region), $7.75 \%$ (Tianjin, CC region), 20.87\% (Ningbo, HS/CW region) and $13.27 \%$ (Shenzhen, HS/WW region) can be achieved respectively from the view of base cases. The optimum strategies show relatively remarkable performance of energy efficiency. The theoretical payback periods, considering the increasing investments of the optimum strategies on the basis of the initial strategies in design stage, were proved to be no more than 1.5 years. The economic benefits were proper if the PEEEMs strategies were optimized during design phase.

Acknowledgments: The work is supported by the National Key R\&D Program of China (Project No. 2016YFB0601700). The authors are particularly grateful to the owners of case buildings for providing building information.

Author Contributions: Zhaoxia Wang conducted the simulation, analyzed the data and wrote the manuscript; Jing Zhao conceived and designed the research and improved the paper.

Conflicts of Interest: The authors declare no conflict of interest.

\section{References}

1. Hasan, O.A.; Defer, D.; Shahrour, I. A simplified building thermal model for the optimization of energy consumption: Use of a random number generator. Energy Build. 2014, 82, 322-329. [CrossRef]

2. Liu, L.; Zhao, J.; Liu, X.; Wang, Z. Energy consumption comparison analysis of high energy efficiency office buildings in typical climate zones of China and U.S. based on correction model. Energy 2014, 65, 221-232. [CrossRef]

3. Hopfe, C.; McLeod, R. The Passivhaus Designer's Manual: A Technical Guide to Low and Zero Energy Buildings; Routledge: Lindon, UK, 2015; pp. 1-2.

4. Voss, K.; Herkel, S.; Pfafferott, J.; Lohnert, G.; Wagner, A. Energy efficient office buildings with passive cooling-Results and experiences from a research and demonstration programme. Sol. Energy 2007, 81, 424-434. [CrossRef]

5. Gou, Z.; Lau, S.Y. Contextualizing green building rating systems: Case study of Hong Kong. Habitat Int. 2014, 44, 282-289. [CrossRef]

6. Zhang, M.; Wang, M.; Jin, W.; Xia-Bauer, C. Managing energy efficiency of buildings in China: A survey of energy performance contracting (EPC) in building sector. Energy Policy 2018, 114, 13-21. [CrossRef]

7. Ministry of Housing and Urban-Rural Development of the People's Republic of China (MOHURD); General Administration of Quality Supervision, Inspection and Quarantine of the People's Republic of China(AQSIQ). Design Standard for Energy Efficiency of Public Buildings (GB50189-2005); China Architecture \& Building Press: Beijing, China, 2005; pp. 5-12.

8. Ministry of Housing and Urban-Rural Development of the People's Republic of China (MOHURD); General Administration of Quality Supervision, Inspection and Quarantine of the People's Republic of China(AQSIQ). Design Standard for Energy Efficiency of Public Buildings (GB50189-2015); China Architecture \& Building Press: Beijing, China, 2015; pp. 8-13.

9. Geng, G.; Wang, Z.; Zhao, J.; Zhu, N. Suitability assessment of building energy saving technologies for office buildings in cold areas of China based on an assessment framework. Energy Convers. Manag. 2015, 103, 650-664. [CrossRef]

10. Lu, S.; Wang, R.; Zheng, S. Passive Optimization Design Based on Particle Swarm Optimization in Rural Buildings of the Hot Summer and Warm Winter Zone of China. Sustainability 2017, 9, 2288. [CrossRef] 
11. Lu, S.; Tang, X.; Ji, L.; Tu, D. Research on Energy-Saving Optimization for the Performance Parameters of Rural-Building Shape and Envelope by TRNSYS-GenOpt in Hot Summer and Cold Winter Zone of China. Sustainability 2017, 9, 294. [CrossRef]

12. Zhou, S.; Zhao, J. Optimum combinations of building envelop energy-saving technologies for office buildings in different climatic regions of China. Energ. Build. 2013, 57, 103-109. [CrossRef]

13. Wang, Z.; Ding, Y.; Geng, G.; Zhu, N. Analysis of energy efficiency retrofit schemes for heating, ventilating and air-conditioning systems in existing office buildings based on the modified bin method. Energy Convers. Manag. 2014, 77, 233-242. [CrossRef]

14. Østergård, T.; Jensen, R.L.; Maagaar, S.E. Early Building Design: Informed decision-making by exploring multidimensional design space using sensitivity analysis. Energy Build. 2017, 142, 8-22. [CrossRef]

15. Yang, L.; Lam, J.C.; Tsang, C.L. Energy performance of building envelopes in different climate zones in China. Appl. Energy 2008, 85, 800-817. [CrossRef]

16. Yu, J.; Yang, C.; Tian, L. Low-energy envelope design of residential building in hot summer and cold winter zone in China. Energy Build. 2008, 40, 1536-1546. [CrossRef]

17. Moon, D.; Sagisaka, M.; Tahara, K.; Tsukahara, K. Progress towards Sustainable Production: Environmental, Economic, and Social Assessments of the Cellulose Nanofiber Production Process. Sustainability 2017, 9, 2368. [CrossRef]

18. Ghione, A.; Noel, B.; Vinai, P.; Demazière, C. Uncertainty and sensitivity analysis for the simulation of a station blackout scenario in the Jules Horowitz Reactor. Ann. Nucl. Energy 2017, 104, 28-41. [CrossRef]

19. Shirvan, K.M.; Soroush Mirzakhanlari, S.; Mamourian, M.; Hamdeh, N.A. Numerical investigation and sensitivity analysis of effective parameters to obtain potential maximum power output: A case study on Zanjan prototype solar chimney power plant. Energy Convers. Manag. 2017, 136, 350-360. [CrossRef]

20. Lam, C.; Wan, K.; Yang, L. Sensitivity analysis and energy conservation measures implications. Energy Convers. Manag. 2008, 49, 3170-3177. [CrossRef]

21. Aranda, J.; Zabalza, I.; Conserva, A.; Millán, G. Analysis of Energy Efficiency Measures and Retrofitting Solutions for Social Housing Buildings in Spain as a Way to Mitigate Energy Poverty. Sustainability 2017, 9 , 1869. [CrossRef]

22. Stutterecker, W.; Blumel, E. Energy plus standard in buildings constructed by housing associations. Energy 2012, 48, 56-65. [CrossRef]

23. Arima, Y.; Ooka, R.; Kikumoto, H. Proposal of typical and design weather year for building energy simulation. Energy Build. 2017, 139, 517-524. [CrossRef]

24. ASHRAE. Measurement of Energy and Demand Savings; ASHRAE Guideline 14-2002; American Society of Heating, Refrigerating and Air-Conditioning Engineers Inc.: Atlanta, GA, USA, 2012.

25. Zhang, A.; Bokel, R.; Dobbelsteen, A.; Sun, Y.; Huang, Q.; Zhang, Q. The Effect of Geometry Parameters on Energy and Thermal Performance of School Buildings in Cold Climates of China. Sustainability 2017, 9, 1708. [CrossRef]

26. Ministry of Housing and Urban-Rural Development. Design Standard for Energy Efficiency of Public Buildings (GB 50189-2005); China Architecture \& Building Press: Beijing, China, 2005; pp. 4-14.

27. Tian, W.; Song, J.; Li, Z.; Wilde, P. Bootstrap techniques for sensitivity analysis and model selection in building thermal performance analysis. Appl. Energy 2014, 135, 320-328. [CrossRef]

28. Xiao, S.; Lu, Z.; Xu, L. Multivariate sensitivity analysis based on the direction of eigen space through principal component analysis. Reliab. Eng. Syst. Saf. 2017, 165, 1-10. [CrossRef]

29. Shao, Q.; Younes, A.; Fahs, M.; Mara, T.A. Bayesian sparse polynomial chaos expansion for global sensitivity analysis. Comput. Methods Appl. Mech. Eng. 2017, 318, 474-496. [CrossRef]

30. Lammoglia, S.; Makowski, D.; Moeys, J.; Justes, E.; Barriuso, E.; Mamy, L. Sensitivity analysis of the STICS-MACRO model to identify cropping practices reducing pesticides losses. Sci. Total Environ. 2017, 580, 117-129. [CrossRef] [PubMed]

31. Rodriguez, G.C.; Andres, A.; Munoz, F.; Lopez, J.; Zhang, Y. Uncertainties and sensitivity analysis in building energy simulation using macroparameters. Energy Build. 2013, 67, 79-87. [CrossRef]

32. Sanchez, D.G.; Lacarriere, B.; Musy, M.; Bourges, B. Application of sensitivity analysis in building energy simulations: Combining first-and second-order elementary effects methods. Energy Build. 2014, 68, 741-750. [CrossRef] 
33. O'Neill, Z.; Niu, F. Uncertainty and sensitivity analysis of spatio-temporal occupant behaviors on residential building energy usage utilizing Karhunen-Loève expansion. Build. Environ. 2017, 115, 157-172. [CrossRef]

34. Fang, Z.; Li, N.; Li, B.; Luo, G.; Huang, Y. The effect of building envelope insulation on cooling energy consumption in summer. Energy Build. 2014, 77, 197-205. [CrossRef]

35. Reda, F.; Tuominen, P.; Hedman, Å.; Ibrahim, M.G.E. Low-energy residential buildings in New Borg El Arab: Simulation and survey based energy assessment. Energy Build. 2015, 93, 65-82. [CrossRef]

36. Zhang, N.; Smith, S.; Bulatov, I.; Klemes, J. Sustaining high energy efficiency in existing processes with advanced process integration technology. Appl. Energy 2013, 101, 26-32. [CrossRef]

37. Laurent, M.; Fariborz, H. Multiobjective optimization of building design using TRNSYS simulations, genetic algorithm, and Artificial Neural Network. Build. Environ. 2010, 45, 739-746.

38. Dhaka, S.; Mathur, J.; Garg, V. Combined effect of energy efficiency measures and thermal adaptation on air conditioned building in warm climatic conditions of India. Energy Build. 2012, 55, 351-360. [CrossRef]

39. Yao, J.; Zhu, N. Evaluation of indoor thermal environmental, energy and daylighting performance of thermotropic windows. Build. Environ. 2012, 49, 283-290. [CrossRef]

40. Sadeghi, S.A.; Karava, P.; Konstantzos, I.; Tzempelikos, A. Occupant interactions with shading and lighting systems using different control interfaces: A pilot field study. Build. Environ. 2016, 97, 177-195. [CrossRef]

41. Salvalai, G.; Pfafferott, J.; Sesana, M.M. Assessing energy and thermal comfort of different low-energy cooling concepts for non-residential buildings. Energy Convers. Manag. 2013, 76, 332-341. [CrossRef]

42. Pfafferott, J.; Herkel, S.; Wambsganß, M. Design, monitoring and evaluation of a low energy office building with passive cooling by night ventilation. Energy Build. 2004, 36, 455-465. [CrossRef]

43. Xie, X.; Gou, Z. Building performance simulation as an early intervention or late verification in architectural design: Same performance outcome but different design solutions. J. Green Build. 2017, 12, 45-61. [CrossRef]

44. Friess, W.A.; Rakhshan, K. A review of passive envelope measures for improved building energy efficiency in the UAE. Renew. Sustain. Energy Rev. 2017, 72, 485-496. [CrossRef]

(C) 2018 by the authors. Licensee MDPI, Basel, Switzerland. This article is an open access article distributed under the terms and conditions of the Creative Commons Attribution (CC BY) license (http:/ / creativecommons.org/licenses/by/4.0/). 